\title{
Archaeological Testing at the Headwaters of the San Marcos River: Southwest Texas State University Raw Water Supply Project
}

Anthony S. Lyle

Center for Archaeological Research

Christopher E. Horrell

Center for Archaeological Research

Steve A. Tomka

Raba Kistner

Diane A. Cargill

Center for Archaeological Research

Follow this and additional works at: https://scholarworks.sfasu.edu/ita

Part of the American Material Culture Commons, Archaeological Anthropology Commons, Environmental Studies Commons, Other American Studies Commons, Other Arts and Humanities Commons, Other History of Art, Architecture, and Archaeology Commons, and the United States History Commons

Tell us how this article helped you.

This Article is brought to you for free and open access by the Center for Regional Heritage Research at SFA ScholarWorks. It has been accepted for inclusion in Index of Texas Archaeology: Open Access Gray Literature from the Lone Star State by an authorized editor of SFA ScholarWorks. For more information, please contact cdsscholarworks@sfasu.edu. 


\section{Archaeological Testing at the Headwaters of the San Marcos River: Southwest Texas State University Raw Water Supply Project}

\section{Creative Commons License}

\section{(c) (1) (8)}

This work is licensed under a Creative Commons Attribution-NonCommercial 4.0 International License 


\title{
Archaeological Testing at the Headwaters of the San Marcos River: Southwest Texas State University Raw Water Supply Project
}

\author{
Anthony S. Lyle, Christopher E. Horrell, \\ Steve A. Tomka, and Diane A. Cargill
}

Center for Archaeological Research

The University of Texas at San Antonio Archaeological Survey Report, No. 293 2000

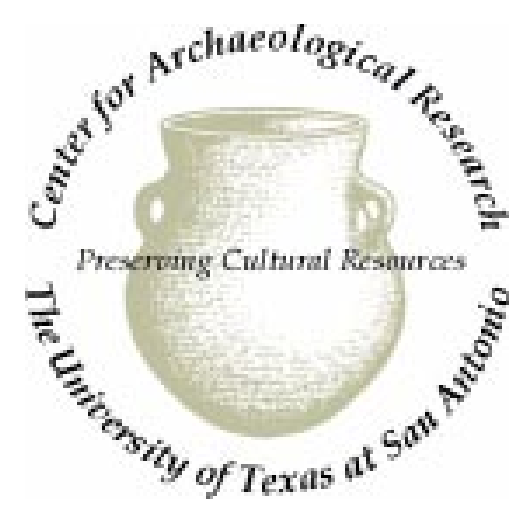




\title{
Archaeological Testing at the Headwaters of the San Marcos River: Southwest Texas State University Raw Water Supply Project
}

\author{
Anthony S. Lyle, Christopher E. Horrell, \\ Steve A. Tomka, and Diane A. Cargill
}

\section{Robert J. Hard and C. Britt Bousman Principal Investigators}

Texas Antiquities Permit No. 2000

Ccopyright 2000

Center for Archaeological Research

The University of Texas at San Antonio Archaeological Survey Report, No. 293 
The following information is provided in accordance with the General Rules of Practice and Procedure, Chapter 41.11 (Investigative Reports), Texas Antiquities Committee:

1. Type of investigation: Testing and Monitoring.

2. Project name: SWTX State University Raw Water Supply Project.

3. County: Hays.

4. Principal investigators: Robert J. Hard and C. Britt Bousman.

5. Name and location of sponsoring agency: Southwest Texas State University, San Marcos, TX 78666-4616.

6. Texas Antiquities Permit No.: 2000.

7. Published by the Center for Archaeological Research, The University of Texas at San Antonio, 6900 N. Loop 1604 W., San Antonio, Texas 78249-0658, 2000

A list of publications offered by the Center for Archaeological Research is available. Call (210) 458-4378; write to the Center for Archaeological Research, The University of Texas at San Antonio, 6900 N. Loop 1604 W., San Antonio, Texas 78249-0658; e-mail to car@lonestar.utsa.edu; or visit CAR's web site at http://csbs3.utsa.edu/car. 


\begin{abstract}
Between April 30 and June 3, 1998, the Center for Archaeological Research of The University of Texas at San Antonio conducted subsurface testing for cultural resources along the proposed route of a water pipeline for Southwest Texas State University. The area to be impacted by the proposed waterline included a tract on the banks of the headwaters of the San Marcos River and tracts adjacent to the Aquatic Biology Building. The project area is partially within the known boundaries of site 41HY161. The archaeological investigations included shovel testing, backhoe trenching, excavation of three 1 x 1-m units, and monitoring. Upon completion, based on the results of this archaeological work, it was determined that no intact cultural resources would be impacted by the planned trench construction between the west bank of the San Marcos River and the southeast corner of the Aquatic Biology Building. However, intact cultural deposits were identified west of the Aquatic Biology Building dating to the late Paleoindian and Archaic periods. Therefore, clearance for the pipeline route was recommended in areas that did not contain cultural resources and in areas disturbed by recent or historic construction. To avoid disturbance to intact cultural materials, Southwest Texas State University was required to modify the depth of the pipeline trench west of the Aquatic Biology Building.
\end{abstract}




\section{Contents}

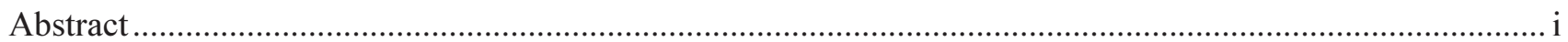

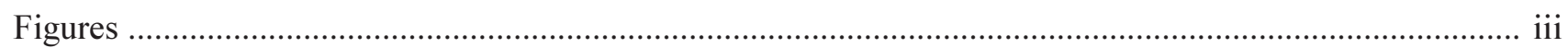

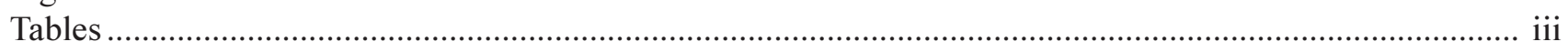

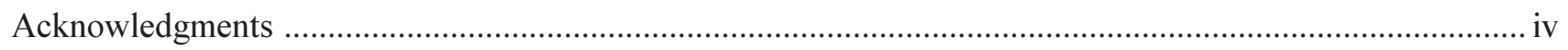

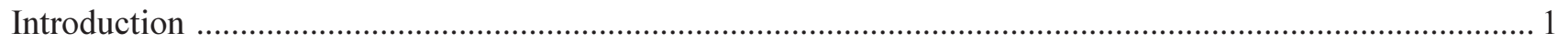

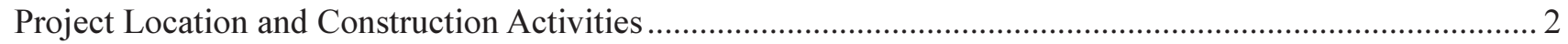

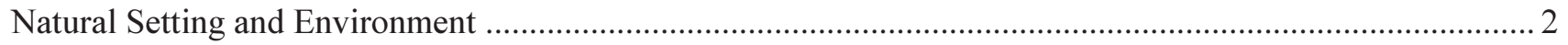

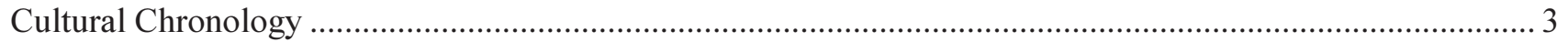

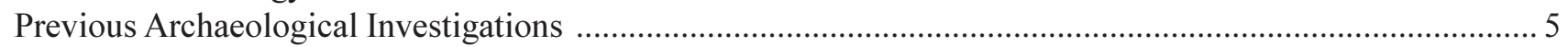

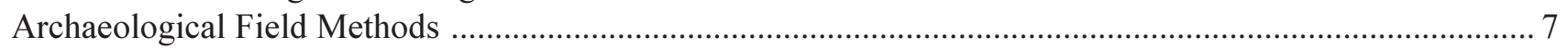

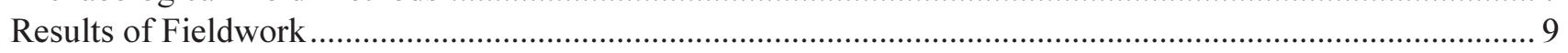

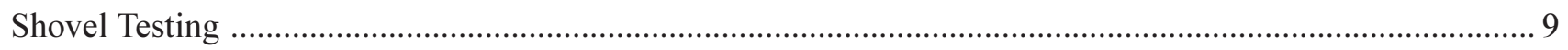

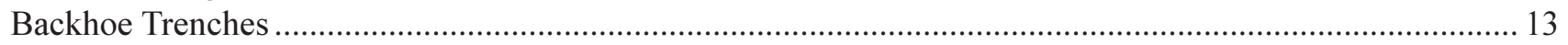

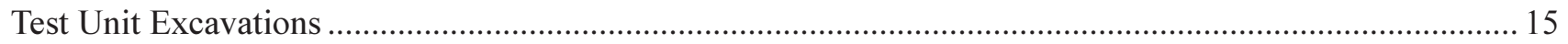

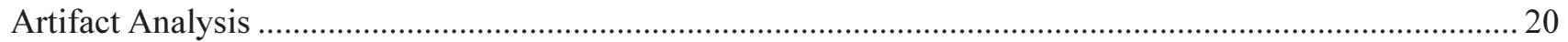

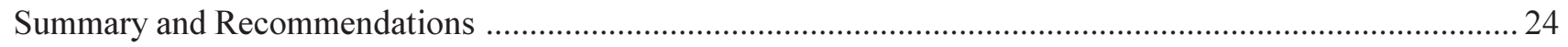

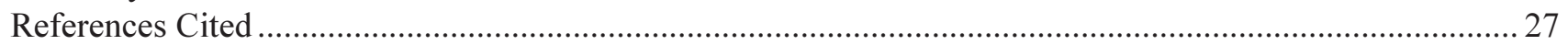

Appendix 1

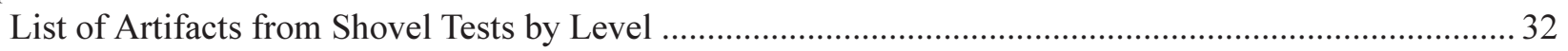

Appendix 2

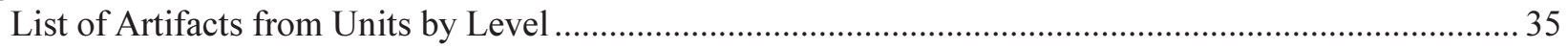




\section{Figures}

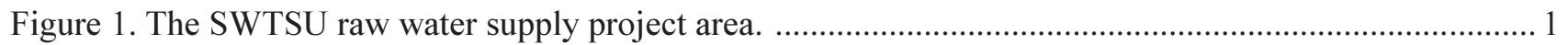

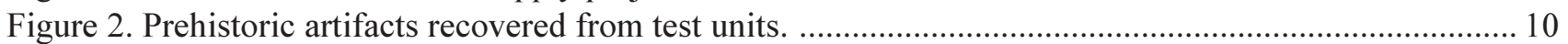

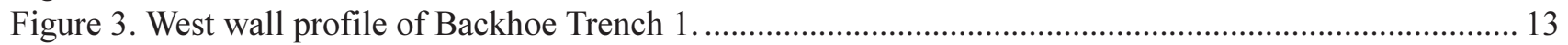

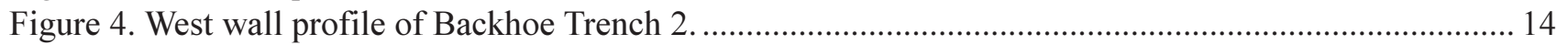

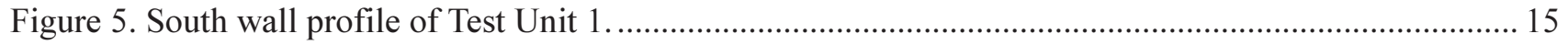

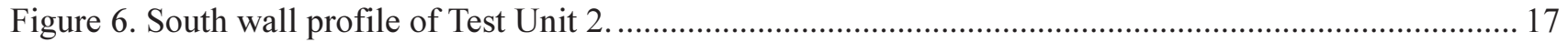

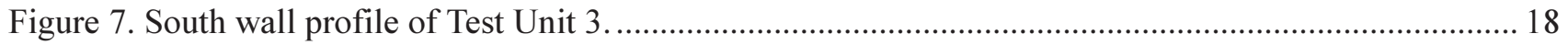

Figure 8. Distribution of debitage quantities within test units by excavation level. ..................................... 22

\section{Tables}

Table 1. Artifacts recovered from shovel tests located in Section 1 (STs 1-12) ............................................ 9

Table 2. Breakdown of artifacts from shovel tests in Section 1 (STs 1-12) by level ..................................... 9

Table 3. Artifacts recovered from shovel tests located in Section 2 (STs 13-17) ....................................... 11

Table 4. Breakdown of artifacts from shovel tests in Section 2 (STs 13-17) by level ................................. 11

Table 5. Artifacts recovered from shovel tests located in Section 3 (STs 18-19) ........................................ 11

Table 6. Breakdown of artifacts from shovel tests in Section 3 (STs 18-19) by level .................................. 11

Table 7. Artifacts recovered from shovel tests located in Section 4 (STs 20-26) ......................................... 12

Table 8. Breakdown of artifacts from shovel tests in Section 4 (STs 20-26) by level .................................. 12

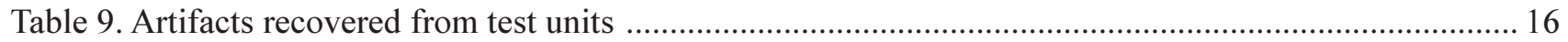

Table 10. Breakdown of artifacts from all test units combined by level ..................................................... 17

Table 11. Breakdown of unmodified debitage size characteristics by level within the three test units ............23 


\section{Acknowledgments}

The authors would like to thank several SWTSU personnel for their assistance, especially Allen Henderson and Donald Lackstedt, Facilities Planning and Design Services; Ed McGee, Grounds Maintenance Services; and Edwin Fauver, Jr., Director of Physical Plant. Thanks to Kat Brown and Chris Ringstaff for their information and experience working in the soils around Spring Lake. Thanks to Dr. Robert J. Hard and Dr. C. Britt Bousman, principal and co-principal investigators, respectively, for their support in this project. Appreciation is due to Chris Butler and Bruce Moses for the digital maps and to Maryanne King, our technical editor. The authors would also like to extend special thanks to Lyla Ethridge and to Francis Stovall of the Hays County Historical Society. Francis provided valuable information on the early history of the dam and mills on the San Marcos River and donated reference materials to the CAR library. We appreciate the help of staff archeologists Preston McWhorter, Ricky Robinson, Gloria Murguia, and volunteer Clemente Murguia. Special thanks to Brad Vierra, former CAR staff archaeologist who directed the initial fieldwork and managed various behind-the-scenes duties on this project. 


\section{Introduction}

Between April 30 and June 3, 1998, Southwest Texas State University (SWTSU) contracted the Center for Archaeological Research (CAR) of The University of Texas at San Antonio (UTSA) to conduct a testing project to identify and record cultural deposits which might be impacted by a proposed raw water pipeline to be built between Spring Lake and a nearby chiller plant. The property under consideration is owned by SWTSU. The proposed pipeline route lies partially within site $41 \mathrm{HY} 161$ and in the immediate vicinity of sites 41HY147, 41HY160, and 41HY165 (Shiner 1979, 1983; Garber et al. 1983; Garber and Orloff 1984). The project's close proximity to rich archaeological deposits as well as other historical landmarks (i.e., the Burleson dam, mill, and the Old Icehouse) reinforced the need for archaeological investigations (Ford and Lyle 1998). In compliance with the Texas Antiquities Code, the archaeological work was performed under Texas Antiquities Permit No. 2000.

The project's scope of work included the performance of three principal tasks: testing for intact cultural materials through the excavation of a series of shovel test (STs) and backhoe trenches (BHTs); describing the two bore pits associated with the pipeline construction; and monitoring the installation of a section of the pipeline. Following the discovery of intact cultural deposits in the area west of the Aquatic Biology Building, three test units (TUs) were excavated to define the nature and content of these deposits.

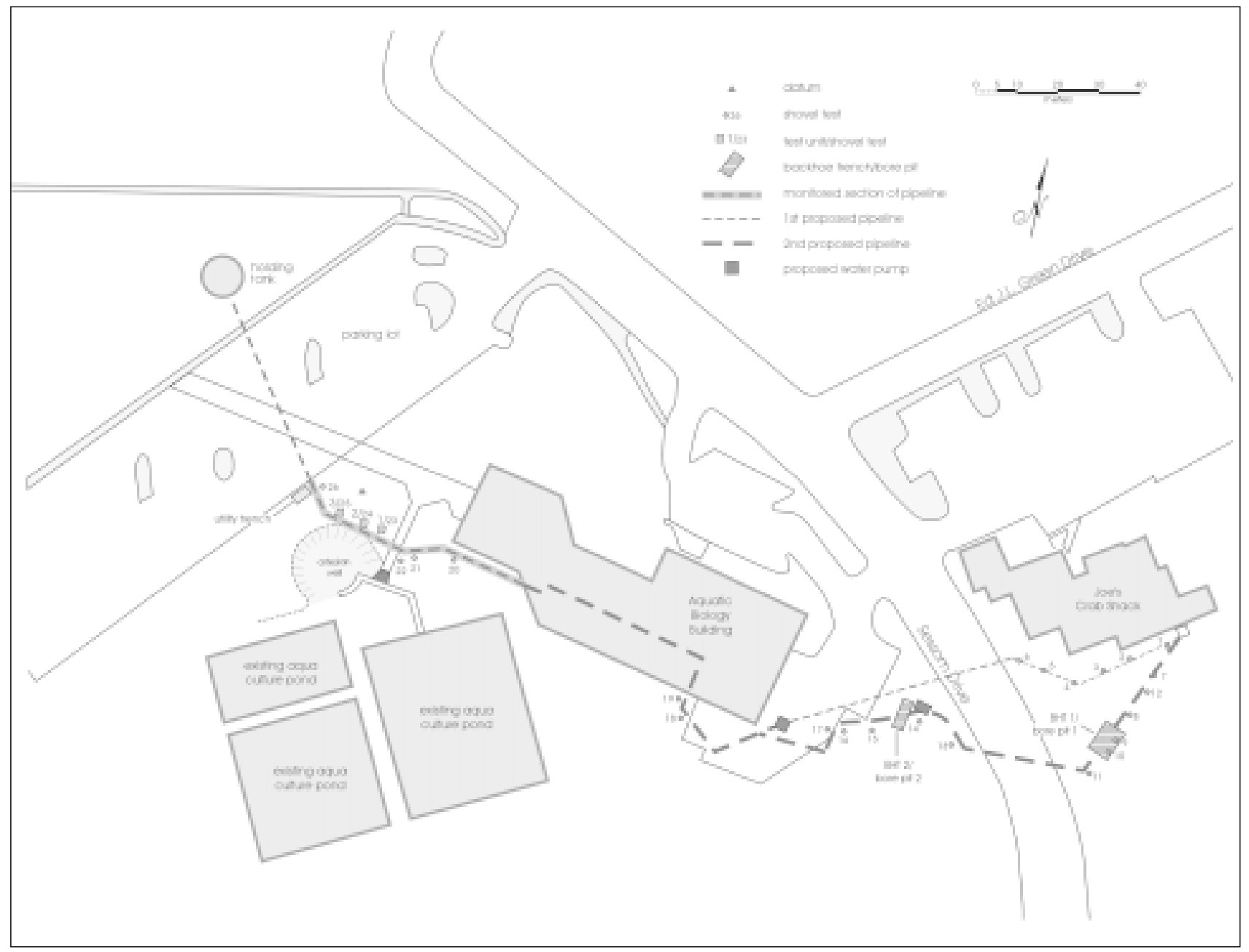

Figure 1. The SWTSU raw water supply project area. 
The shovel-testing portion was conducted under the direction of project archaeologist Brad Vierra, while the $1 \times 1 \mathrm{~m}$ unit excavation phase was directed by Tony Lyle, and Chris Horrell oversaw the monitoring of a section of the pipeline. Dr. Robert J. Hard and Dr. C. Britt Bousman served as principal and co-principal investigators, respectively. In addition, Dr. Bousman described the geological profiles included in this report. The fieldwork was completed in 25 person days. Steve A. Tomka analyzed the lithic debitage and wrote the artifact descriptions. Diane Cargill and Tomka organized and prepared the manuscript for publication.

\section{Project Location and Construction Activities}

The project area is located in southern Hays County, Texas. It is on property owned by SWTSU located in the City of San Marcos. The raw water pipeline begins at Joe's Crab Shack, crosses under Sessom Drive, and runs to the southeast corner of the Aquatic Biology Building. From here it continues along the south edge of this building, and extends northwest to a 5000 gallon holding tank (Figure 1).

Pipeline construction activities carried out by DuMore Construction included the excavation of a linear trench, two bore pits, and a pit for a concrete-lined pump station. The majority of the trench was three feet wide and three feet deep. A section of this trench, located in the west lawn of the Aquatic Biology Building, was to be dug to a depth of no more than 13 inches.

The two bore pits were excavated to install the pipeline under Sessom Drive (Figure 1). The first bore pit (BP 1) was excavated to a depth of approximately 3 meters ( 10 feet) and was 4.5 meters ( 15 feet) long and 9 meters (30 feet) wide. The second bore pit (BP 2), which was visibly smaller, was excavated west of Sessom Drive.

Two additional pits, apparently intended for pump stations, were to be excavated in the area west of and adjacent to Sessom Drive. The excavation of these pits was not monitored, and no further investigation was conducted regarding the pump stations.

\section{Natural Setting and Environment}

The project area is located adjacent to the dam at Spring Lake and the headwaters of the San Marcos River, which emanate from the edge of the Balcones Escarpment. This region is within the Balconian Biotic Province (Blair 1950) and the Juniper-Oak-Mesquite Savanna vegetation area (Black 1989a). It also represents the transition zone between the Edwards Plateau and the Blackland Prairie (Arnn 1997; Ricklis et al. 1991).

The Edwards Plateau is characterized by heavily dissected tableland with shallow soils and deep canyons cut by numerous streams (McCulloch and Voellinger 1996:4). Many of these streams are spring-fed, originating along the fault of the Balcones Escarpment. Oakalla (Ok) and Tinn (Tn) soils are common within the project area (Batte 1984). The frequently flooded Oakalla silty clay loams are deep, nearly level soils found on smooth to slightly undulating floodplains. They are comprised of loam, clay loam, silty clay, or silty clay loam, and are moderately alkaline and calcareous, containing about 60 percent calcium carbonate. This moderately permeable soil is seasonally flooded every two to three years. Tinn clays are "deep, nearly level soils on flood plains along small streams" (Batte 1984:41). These soils are moderately alkaline, calcareous, and poorly drained. Archaeological investigations in and near the project area have documented deeper soils characterized by red clay deposits. These soils are known to contain Prehistoric cultural material (Ford and Lyle 1998; Shiner 1983).

According to Ogden et al. (1986:116), "the San Marcos Springs are the second largest spring group in Texas with a mean flow of 161 cubic feet per second (cfs; $4.50 \mathrm{~m}^{3} / \mathrm{sec}$ )." The maximum-recorded discharge occurred in 1973, with $300 \mathrm{cfs}$ and the minimum discharge was recorded on August 15, 1956, with 89 cfs. There are six major springs with numerous smaller openings that maintain a constant temperature of $71^{\circ}$ F. According to Brune (1981:223), "the Tonkawas called them Canocanayesatetlo, meaning warm water, although they are only very slightly warm." It is estimated that there were over 200 springs when the Spanish explorers first discovered them (Brune 1975:45). Spring Lake was created in 1849 by the 
construction of an earthen dam at the headwaters of the San Marcos River by Edward Burleson (Brune 1975, 1981; McCulloch and Voellinger 1996; Shiner 1983). This dam has been rebuilt over the years, but it is apparently in the same location as the one Burleson constructed. Today, the lake has a maximum depth of 12.2-m (40 feet) and is at an elevation of 175-m (574 feet) above sea level (Brune 1981; Garber et al. 1983; Ogden et al. 1986). The natural springs, flowing at 150 to 300 million gallons a day from the Edwards Aquifer, attract and support an abundance of flora and fauna (Brune 1981; Shiner 1983).

The modern landscape supports juniper (cedar), mesquite, cottonwood, oak, pecan, and bald cypress (Blair 1950; Ricklis and Collins 1994). These species were present in Prehistoric times as well. Blair (1950) lists 49 species of mammals, 2 land turtles, 16 lizards, 39 snakes, and 23 amphibians present in the Balconian Biotic Province.

Species that no longer inhabit the region include bear, bison, wolf, and antelope (Black 1989a). Three federally listed endangered species are present in the San Marcos River and Spring Lake riparian environment (Cargill and Brown 1997:4). They are the San Marcos salamander (Eurycea nana), the fountain darter (Etheostoma fonticola), and the San Marcos gambusia (Gambusia georgei). This natural spring environment has been a location for human habitation and resource procurement for a long and uninterrupted period of time, beginning with the Paleoindian period (ca. 11,500-8800 BP).

\section{Cultural Chronology}

\section{Paleoindian (ca. 11,500-8800 BP)}

While Paleoindian land use strategies can be described as well adapted to the hunting of large game, they also included a significant gathering (e.g., plants and mussel shell) and small game-hunting component (Collins 1995). Shiner (1983) and Takac (1990) suggest that the early hunters and gatherers of Central Texas relied on fresh-water spring environments. Site 41HY160 located around Spring Lake produced Paleoindian materials.

\section{Archaic (ca. 8800-1200 or 1300 BP)}

The Archaic period in Central Texas has been divided into three subperiods: Early Archaic (8800-6000 BP), Middle Archaic (6000-4000 BP) and Late Archaic (4000-1200 or 1300 BP). As in the Paleoindian period, the people of the Archaic continued to utilize and exploit the natural spring environments along the Balcones Escarpment. One possible explanation for continued dependence on perennial water sources is the increasingly arid conditions that prevailed particularly in the Middle Archaic (Black 1989b; Bousman 1998; Collins 1995; McKinney 1981). Archaic period materials have been found at sites 41HY37, 41HY147, 41HY160, and 41HY165.

\section{Late Prehistoric (ca. 1200-350 BP)}

The Late Prehistoric is marked by the advent of the bow and arrow and ceramic technology. This period is divided into two phases: the Austin Phase (ca. AD 800-1300) and the Toyah Phase (ca. AD 1300-1600). Technological markers for the Austin Phase include the introduction of the bow and arrow and the use of expanding stem points such as Scallorn (Black 1989b; McCulloch and Voellinger 1996). The Toyah Phase marks the appearance of bone-tempered pottery and Perdiz arrow points (Collins 1995; McCulloch and Voellinger 1996). Toyah Phase sites also exhibit evidence of increased Caddoan interaction from northeastern Texas (McCulloch and Voellinger 1996:11). The springs environment continued to be an important resource area during the Late Prehistoric period. Sites that have yielded Late Prehistoric material around Spring Lake include 41HY37, 41HY160, and 41HY165.

\section{Protohistoric (ca. 1528-1755)}

The Protohistoric period is defined by Hester (1995:449-450) as "the transition period between the Prehistoric and Historic periods denoting a phase for which few written records are available, and for which most evidence is derived from archaeology." Cabeza de Vaca's accidental exploration of the Texas coast and surrounding areas marks the beginning of the Protohistoric Period, and the establishment of Spanish missions in Texas represents the beginning of the Historic Period. 
During the Protohistoric period, little direct contact occurred between European and Native American groups, and very few written records were produced. Indigenous groups continued to exploit the same resources as they did in the Late Prehistoric Period. Contact between European and native groups occurred with the direct introduction of European material culture through both primary and secondary trade. Many groups were displaced from their territories during Spanish colonization of Nuevo Leon (Salinas 1990) and as the Spaniards continued their northward and eastward expansion over the next 150 years (Campbell and Campbell 1985; Salinas 1990). Displacement of native groups also occurred when mounted Apache began moving southeastward from the southern High Plains and again around 1750 when the Apache, with the aid of the horse, moved onto the coastal plain (Campbell and Campbell 1985).

The headwaters of the San Marcos River have provided a source of water for many different groups of people. The river was named for the Feast of San Marcos (Bolton 1908:370). Undoubtedly, many Spanish expeditions explored the river valley and scholars believe that the name San Marcos was attributed to several rivers in the region. It appears that the river was first described during the Espinosa-OlivaresAguirre expedition of 1709 (Foster 1995:103-104). These travelers found the river valley teaming with a variety of life. They described the area as rich in grapes, nuts, and hemp, and the river as full of a variety of fish. They also noted bears, wolves, foxes, mountain lions, turkeys, and large numbers of deer. The Indians they encountered appeared friendly and exchanged nuts for tobacco and brown sugar. It is during the Espinosa-Olivares-Aguirre expedition, and subsequent expeditions that the Camino de las Tejas was created. This road system, based on ancient Indian trails, extended from the area around the Colorado River near Del Valle to the first location of the San Xavier Missions on San Xavier River (now known as the San Gabriel River), near Rockdale. The route crossed the San Marcos River approximately 200 yards below the springs (Jones 1997:1; McGraw et al. 1991:187). Within the immediate project area, the Protohistoric period lasts until 1755, when Spanish missions and a presidio were established near the San Marcos River (McCulloch and Voellinger 1996).

\section{Historic (1755-present)}

By 1755, the San Xavier missions were moved without permission to the San Marcos River due to tension with the presidio commander, problems with the Indians, and the unpredictable weather (Gilmore 1969:38). These missions included San Francisco de Horcasitas, Mission Nuestra Señora de la Candelaria and San Ildefonso, and the presidio of San Francisco Xavier that was attached to the missions for protection. The missions came to the San Marcos River near the springs "complete with bells, ornaments and other mission property, and forty Indian Neophytes" (Gilmore 1969:38). During their tenure at least 1000 Apache Indians joined the Mission. By 1757 the friars wanted to move to Apache territory. Subsequently, upon royal approval, these missions were split up. Some neophytes were transferred to the San Antonio Missions, some to the ill-fated Santa Cruz de San Sabá Mission (on the San Saba River), and the rest were moved to a new mission on the Guadalupe River, near present-day New Braunfels (Bolton 1915:85).

The Louisiana Purchase in 1803 forced the Spanish to examine the San Marcos River as a viable area for settlement. On the banks of the river, just below the confluence of the Blanco and San Marcos rivers, approximately 3 miles from the present-day City of San Marcos, the Villa de San Marcos de Neve was established in 1808 . Financed by the provincial governor of Texas, Colonel Don Antonio Cordero y Bustamante commissioned Don Filipe Roque de la Portilla to establish the settlement. Portilla brought 82 people from the interior of Mexico where they were to establish a cattle ranching industry. However, the settlement was doomed from the beginning. On June 5,1808 , a flood swept through the plaza of the town and forced the inhabitants to flee to higher ground. In addition, Indian attacks and the lack of government support forced the town to abandon the area and return to Mexico in 1812 (Hatcher 1927).

Mexico won its independence from Spain in 1821. Soon thereafter, in 1824, Texas and Coahuila became independent states under the flag of Mexico (Tijerina 1994:98). Texas was combined with Coahuila to create one state within Mexico. Juan Martin de Veramendi, born in Bexar in 1788, would play an 
important role in the history of Texas shortly after independence. In 1825, Veramendi was granted 11 leagues under the Colonization Law. Two leagues of this land grant contained the old San Marcos de Neve colony as well as the area of the headwaters of the San Marcos River. Upon his death in 1833, the grants were divided and his daughter, Josepha Garza inherited the league of land to the east of the river. The land was then sold to William L. Lindsey and to Edward Burleson. Litigation between these two individuals resulted in the division of the property.

Edward Burleson helped establish the present town of San Marcos in the 1840s. He oversaw "the construction of a dam and saw and gristmill on the San Marcos River near the Springs in 1849" (McCulloch and Voellinger 1996:12). Burleson's mill was the first of five historic mills established in San Marcos (McCulloch and Voellinger 1996). The original dam was approximately 400 feet in length. The eastern section crossed the channel at a right angle for two-thirds the length. The remaining portion deflected water parallel to the west-bank to form a forebay. The dam was constructed of earth and piling and had a maximum height of 15 feet. The turbine water-wheel for the mill was designed and built by craftsmen Ezell and William Firebaugh.

Upon Burleson's death in 1851 the property was left to his heirs. In 1855, the sawmill, gristmill, and a cotton gin house were sold. This property, and the adjoining 40 acres of land, would become known as the Mill Tract in later deeds and legal documents. From 1855 to 1899 , at least 20 transfers of title occurred. In 1883, Tom Code bought the mill tract and established the first ice factory. His machinery would only produce one ton of ice a day or approximately 40 blocks of ice weighing 25 pounds each. Code sold the tract to Ed. J. L. Green in 1889, and in 1894, modern equipment was installed in the Ice House. Ice wagons would come and go selling ice to the residents and merchants of San Marcos. Blocks of ice would last an average household 2 to 3 days (Boxall 1976).

During this time, while the saw, gristmill, and ice plant were in operation on the west-side of the river, a cotton gin owned by Green was in operation on the east bank. According to the U.S. Geological Survey in 1904, a new structure was built on the mill tract. This new structure incorporated the original Ice Factory building, and was managed by three distinct companies (i.e., San Marcos Electric Light and Power Co., the San Marcos Water Co., and the San Marcos Ice Co.). This structure is designated as a State Historical Landmark and is currently part of Joe's Crab Shack. By 1909, the San Marcos Utilities Company was formed, merging the above utilities and sewage operations within the mill tract. At the time of the merger, the Electric Light Co. may have been on the east-side of the river. By 1925, the mills and gin house were no longer in use. San Marcos Utilities Co. sold two parcels of the mill tract to the Texas Public Utilities (Boxall 1976). This sale included all buildings and machinery on the property. By 1940, the Lower Colorado River Authority took over the tract to phase it out of the utilities industry. In 1957, Paul Rogers bought the dam and incorporated it into the Aquarena Springs amusement park. The following year, Southland Ice Company bought the ice factory tract and began to produce 40-45 tons of ice a day. However, by the 1970s ice production dwindled because of the accessibility of electric refrigeration. In 1976, the ice factory was closed permanently (Boxall 1976). By 1982, the old Ice House building on the mill tract became Pepper's Restaurant. The property was later purchased by Southwest Texas State University and leased to Joe's Crab Shack in late-1997 (Ford and Lyle 1998).

\section{Previous Archaeological Investigations}

Regional and local archaeological investigations relevant to the project area have been conducted during the past two decades. These projects have identified archaeological evidence for human occupation spanning all major culture history periods. Archaeological sites associated with the Balcones Escarpment, including the Spring Lake vicinity, consist of open camps, burned rock midden sites, lithic procurement (Black 1989b) and other special use sites such as Timmeron rock shelters (Harris 1985), and burial sites (41HY161). Archaeological work includes underwater investigations at the Ice House Site (41HY161; Shiner 1979, 1983) and excavations at $41 \mathrm{HY} 147$. Cultural materials ranging from the Paleoindian to the Late Prehistoric periods were recovered from the Ice 
House Site. Archaeological investigation of 41HY147 by Southern Methodist University resulted in the excavation of over 200 square meters (McCulloch and Voellinger 1996; Takac 1990) and the recovery of "several hundred thousand artifacts from the lakebed surface from both disturbed and undisturbed areas in the vicinity" (McCulloch and Voellinger 1996:8).

Archaeological investigations conducted by SWTSU field schools since 1982 have resulted in the excavation of numerous sites located around Spring Lake including 41HY37, 41HY160, 41HY161, and 41HY165 (Garber and Orloff 1984; Garber et al. 1983; Ringstaff and Brown, personal communications). Site 41HY165 was recorded in 1984. It is on the southeastern shore of Spring Lake, on the floodplain of the San Marcos River. The site contained bifaces, and debitage but yielded no temporally-diagnostic artifacts (Garber et al. 1983).

Site 41HY160 was recorded and tested by SWTSU in 1982. Artifacts recovered range in age from Paleoindian to the Late Prehistoric periods (Garber et al. 1983; McCulloch and Voellinger 1996). The deepest excavation unit extended below the water table at $2.65 \mathrm{~m}$ below surface and sterile soil was not encountered. Over 500 stone tools and more than 35,000 pieces of lithic debitage were collected, including cores, flakes, bifaces, and projectile points. Three bone tools and several hundred pieces of animal bone were recovered, representing bison, deer, and pronghorn antelope. Also recovered were portions of three sandstone grinding slabs, and 26 pottery sherds including Leon Plain and Caddoan types. Hearths, burned rock middens, stone alignments, a possible ceramic production area, and a posthole were among 13 cultural features recorded. Among the 75 projectile points, 53 are associated with specific chronological periods. These include Alba, Cliffton, Perdiz, and Scallorn points from the Late Prehistoric Period; Darl, Fairland, and Edgewood points from the Late Prehistoric-Late Archaic Transitional Period; Ensor, Frio, Castroville, Pedernales, and Marshall points from the Late Archaic; Bulverde and Nolan points from the Middle Archaic; and Golondrina and a possible Eden/Scottsbluff point from the Paleoindian Period. Temporal affiliations for these points are assigned according to Johnson and Goode (1995). The excavators note that the Golondrina was found at $40 \mathrm{~cm}$ below surface (bs) and the Eden/
Scottsbluff point was recovered at $80 \mathrm{~cm}$ bs. The Bulverde point was found beneath the Paleoindian points in the same excavation unit (McCulloch and Voellinger 1996:9) suggesting some degree of mixture of deposits.

In the 1980s, sites along the Balcones Escarpment and San Marcos River such as 41HY150, 41HY166, 41HY167, and 41HY178, were recorded as Prehistoric campsites. Site 41HY166 contained projectile points from the Middle to Late Archaic, and Late Prehistoric periods (McCulloch and Voellinger 1996:9).

The Historic period site of 41HY164, known as the Thompson's Dam and Mill Race site, was recorded in 1983 by the Texas Archeological Research Laboratory, University of Texas at Austin (McCulloch and Voellinger 1996). It was later nominated to the National Register of Historic Places (McCulloch and Voellinger 1996).

Down river from Spring Lake, site 41HY261 was recorded in 1994 by S. A. Garza Engineers (McCulloch and Voellinger 1996). This site contains cultural materials representative of both the Historic and Prehistoric periods. The Historic component is comprised of a dam, millrace, and mill or pump house, located along and adjacent to the upper terrace. The Prehistoric component is described as an open campsite located on the upper terrace (McCulloch and Voellinger 1996). Recently, the Prehistoric component was tested by CAR. The results of this investigation demonstrate that 41HY261 contains deep, intact, cultural deposits representing ca. 5000 years of Prehistoric cultural activities (Cargill and Brown 1997).

Another recent archaeological testing project in the Spring Lake vicinity, within the boundaries of site 41HY165, was conducted by CAR archaeologists under a contract with SWTSU. This survey and testing project for the construction of a parking lot for Joe's Crab Shack encountered Prehistoric cultural deposits which were disturbed by recent and historic construction activities (Ford and Lyle 1998).

SWTSU field school excavations continue in and around the Spring Lake area. Most of the recent work has concentrated on the Aquarena Springs golf course (Brown and Ringstaff, personal communication 1998). 


\section{Archaeological Field Methods}

Although the entire project area had the potential for containing cultural resources, testing was limited to undeveloped areas, such as the park adjacent the river and the lawns on the southeast and west sides of the Aquatic Biology Building. For management purposes the project area (Figure 1) has been divided into four sections:

\section{Section 1}

An open parklike area adjacent to the river bank and next to Joe's Crab Shack. It begins at the southeast corner of Joe's Crab Shack and extends west to the sidewalk on the eastside of Sessom Drive;

\section{Section 2}

Consists of a small area of lawn south of the Aquatic Biology Building's south parking lot;

\section{Section 3}

Comprised of a small ivy-covered lot under the breezeway of the Aquatic Biology Building; and

\section{Section 4}

West lawn of the Aquatic Biology Building.

After the testing began, engineers made a change in the original route of the pipeline. This only affected Section 1 next to Joe's Crab Shack (Figure 1). The alternate route extended the length of the pipeline and decreased the amount of boring. The total length of the pipeline in the project area was approximately 350 $\mathrm{m}$ (1150 feet) from the dam to the holding tank. Of this, approximately 256 meters ( 840 feet) were tested for the presence of cultural resources.

\section{Shovel Tests}

Twenty-six shovel tests were excavated in the project area. A total of 12 shovel tests (STs 1-12) were dug in Section 1 (Figure 1). Of these, six (STs 1-6) were excavated along the first proposed pipeline route, and the remaining six (STs 7-12) were distributed along the alternate pipeline route. Six ten-centimeter levels were excavated in STs 1, 2, 4, and 9 to depths of 60 $\mathrm{cm}$ bs. Five ten-centimeter levels were excavated in STs $3,5,6,8,10,11$, and 12 to depths of $50 \mathrm{~cm}$ bs. ST 7 was excavated to the third level $(30 \mathrm{~cm} \mathrm{bs})$ and closed due to a large root. Five shovel tests (STs 13-17) were excavated in Section 2 (Figure 1). With the exception of ST 13, which had six levels $(0-60 \mathrm{~cm} \mathrm{bs})$, all others were excavated in five levels $(0-50 \mathrm{~cm} \mathrm{bs})$. Two shovel tests (STs 18 and 19) were excavated in Section 3 (Figure 1). All were dug in five levels $(0-50 \mathrm{~cm}$ bs). Seven shovel tests (STs 20-26) were excavated in Section 4 (Figure 1). STs 20, 21, 22, 25, and 26 were excavated in five levels, while ST 23 contained six and ST 24 contained four levels.

The shovel tests were placed at approximately sixmeter intervals along the original and alternate routes of the pipeline. The soil matrix was screened through $1 / 4$ inch wire mesh and described using standardized procedures for geomorphologic soil descriptions. Information was recorded on standard CAR shovel test forms. Photographs were taken with a Pentax K1000 $35 \mathrm{~mm}$ camera using color print film as part of standard archaeological recording techniques.

All cultural material collected was taken to the CAR laboratory for analysis and curation.

\section{Backhoe Trenches}

Two backhoe trenches (BHTs) were excavated to examine the geological and cultural stratigraphy in the project area (Figure 1). An operator and backhoe were provided by SWTSU, as indicated in the contract. One wall of each BHT was described, profiled, and photographed. The excavation of each backhoe trench was monitored by an archaeologist for cultural deposits.

BHT 1 was placed in Section 1 to investigate the extent of cultural materials documented in STs 9-10, and to explore the potential for deeper deposits that might be impacted during the excavation of BP 1 . BHT 1 was $80 \mathrm{~cm}$ wide, approximately $2.5 \mathrm{~m}$ in length, and $1.4 \mathrm{~m}$ deep.

BHT 2 was located in Section 2 to examine the area to be impacted by BP 2 and one of the pump station pits. BHT 2 was approximately $50 \mathrm{~cm}$ wide, $3 \mathrm{~m}$ long, and $1.7 \mathrm{~m}$ deep. It was oriented north-south so that it cross-cut the proposed pipeline route. Its location was perpendicular to the bank of a small spring-fed tributary known as Sessom Creek. 


\section{Test Units}

Based on preliminary shovel test data, it was determined that Section 4 had the potential for containing undisturbed archeological deposits. Therefore, three $1 \times 1$ meter units were excavated centered on STs 23, 24 , and 25, respectively. All three test units (TUs) were placed in the immediate area to be impacted by the planned water pipeline, in accordance with recommendations by the Texas Historical Commission (THC).

A datum was placed at the base of a large sycamore tree near the center of Section 4 (Figure 1). This was used as a central datum to keep vertical controls consistent for all three units. Surface elevations were taken and the initial level for each unit was excavated to 30 $\mathrm{cm}$ below datum (bd). Succeeding levels in all three units were excavated by trowel and shovel in $10 \mathrm{~cm}$ increments.

Unit 1 was excavated to a depth of $110 \mathrm{~cm}$ below datum $(100 \mathrm{~cm} \mathrm{bs})$, Unit 2 was dug to $90 \mathrm{~cm} \mathrm{bd}(73 \mathrm{~cm}$ bs), while Unit 3 extended to a depth of $100 \mathrm{~cm} \mathrm{bd}$ $(87 \mathrm{~cm} \mathrm{bs})$. The soil matrix was screened through $1 / 4$ inch wire mesh and described using standardized procedures for geomorphologic soil descriptions. Information was recorded on standard CAR unit level forms. Photographs were taken with a Pentax K1000 $35 \mathrm{~mm}$ camera using color print and slide film.

Cultural material was collected and brought to the CAR laboratory for analysis and curation.

\section{Pipeline Trench Monitoring}

The results of the testing phase indicated that to prevent further disturbance to subsurface cultural remains, the excavation of the pipeline trench needed to be monitored. The section of the pipeline trench that was monitored began at the southwest wing of the Aquatic Biology Building and continued to the parking lot west of the building for a distance of approximately $55 \mathrm{~m}$ (180 feet) (Figure 1). Due to the close proximity of the building, the soils were highly disturbed and the trench excavation was permitted to proceed to a depth of 25 inches below the surface. However, once the trench extended past the building onto the creek ter- race, the depth was strictly limited to 13 inches below surface, as discussed with THC personnel (letter: July 9, 1998; to: Allen Henderson, SWTSU Physical Plant, from: James Bruseth, THC Deputy State Historic Preservation Officer). The pipeline excavation was completed using a Caterpillar 426 B CAT backhoe. Additionally, the removal of a portion of the sidewalk using a pneumatic jackhammer was necessary. Throughout the project area several tree roots, sprinkler lines, and electrical lines were encountered. The pipeline was placed in the trench and buried during monitoring.

\section{Utility Trench Inspection}

An exposed utility trench (approx. $2.5 \mathrm{~m}$ x $1 \mathrm{~m}$ x .7 $\mathrm{m}$ ), had been excavated by San Marcos City Utilities crews prior to the beginning of the project at the west end of the project area adjacent the parking lot (Figure 1). The trench was found partially backfilled at the inception of the archaeological fieldwork. As part of CAR's work, the backfill, walls, and floor of the trench were inspected for cultural materials. Brief observations were made regarding the cultural materials observed and the stratigraphy of the unit.

\section{Bore Pit Inspection}

Two bore pits were excavated in the location of the two backhoe trenches. Both bore pits were dug without prior notification of the project archaeologists. The largest of the pits (BP 1) was dug to a depth of 3 meters ( 10 feet) and measured $4.5 \mathrm{~m} \mathrm{x} 9 \mathrm{~m}$ ( 15 feet $\times 30$ feet). It was located on top of BHT 1. A visual inspection of exposed portions of this bore pit was made approximately one week after its excavation. The second bore pit (BP 2) was placed on BHT 2, and was visibly smaller. It was not investigated for cultural resources due to the presence of contaminated soils in the pit. 


\section{Results of Fieldwork}

Shovel Testing

\section{Section 1}

Twelve shovel tests (STs 1-12) were excavated in Section 1 (Figure 1). The soils consisted of clay loam ranging in color from a dark gray brown (10YR4/2), dark reddish brown (5YR3/3), to light gray (5YR7/1), and brown (10YR5/3).

All twelve STs contained a mix of Modern, Historic, and Prehistoric materials (Table 1, Appendix 1).
In all but one shovel test (ST 4; Table 2), the deposits appeared to be moderately to highly disturbed (Table 2 ). As a testament to the degree of disturbance, a 13 $\mathrm{cm}$ thick layer of deteriorated mortar or powdered cement was encountered between $30-42 \mathrm{~cm}$ bs in ST 2 . ST 4 contained undisturbed material below Level 2 (10-20 cm bs).

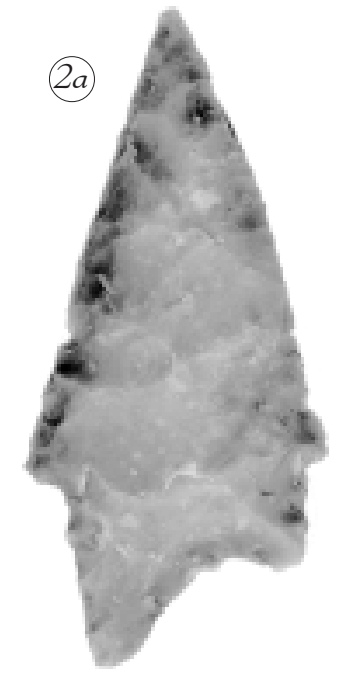

A single diagnostic artifact, a Pedernales projectile point (Figure 2a), was recovered from Level $3(20-30 \mathrm{~cm}$ bs) of ST 3.

Table 1. Artifacts recovered from shovel tests located in Section 1 (STs 1-12)

\begin{tabular}{|c|c|c|c|c|c|c|c|c|c|}
\hline ST\# & $\begin{array}{c}\text { Chipped } \\
\text { Lithic }\end{array}$ & $\begin{array}{c}\text { Animal } \\
\text { Bone }\end{array}$ & $\begin{array}{c}\text { Misc. } \\
\text { Metal }\end{array}$ & Nails & $\begin{array}{c}\text { Misc. } \\
\text { Glass }\end{array}$ & Ceramic & $\begin{array}{c}\text { Constr. } \\
\text { Debris }\end{array}$ & Other & Total \\
\hline 1 & 7 & 5 & 2 & 1 sqr. & 3 & & & 17 & 35 \\
\hline 2 & 7 & 5 & 4 & 1 wire, 2 sqr. & 2 & 1 & 4 & 4 & 30 \\
\hline 3 & 8 & 3 & & & 1 & & & & 12 \\
\hline 4 & 30 & 4 & & & 1 & & & & 35 \\
\hline 5 & 9 & & 1 & 2 sqr. & & 1 & 1 & & 14 \\
\hline 6 & 3 & & & 2 wire & & & & & 5 \\
\hline 7 & 2 & & 1 & 2 wire & 1 & & & 1 & 7 \\
\hline 8 & 14 & & & 2 wire & & & & 1 & 17 \\
\hline 9 & 13 & 7 & 5 & & 2 & 2 & & 20 & 49 \\
\hline 10 & 1 & & & & 2 & & & 19 & 22 \\
\hline 11 & 1 & & & & & & & & 1 \\
\hline 12 & 4 & & 2 & & & & & & 9 \\
\hline Total & $\mathbf{9 9}$ & $\mathbf{2 4}$ & $\mathbf{1 5}$ & $\mathbf{5}$ sqr., $\mathbf{7}$ wire & $\mathbf{1 2}$ & $\mathbf{4}$ & $\mathbf{5}$ & $\mathbf{7 2}$ & $\mathbf{2 4 2}$ \\
\hline
\end{tabular}

Table 2. Breakdown of artifacts from shovel tests in Section 1 (STs 1-12) by level

\begin{tabular}{|c|c|c|c|c|c|c|c|c|c|}
\hline Level & $\begin{array}{c}\text { Chipped } \\
\text { Lithic }\end{array}$ & $\begin{array}{c}\text { Animal } \\
\text { Bone }\end{array}$ & $\begin{array}{c}\text { Misc. } \\
\text { Metal }\end{array}$ & Nails & $\begin{array}{c}\text { Misc. } \\
\text { Glass }\end{array}$ & $\begin{array}{c}\text { Ceramic } \\
\text { Debris }\end{array}$ & $\begin{array}{c}\text { Other } \\
\text { Debral }\end{array}$ & Tot \\
\hline 1 & 14 & 6 & 4 & 1 sqr. 3 wire & 1 & 1 & 2 & 10 & 42 \\
\hline 2 & 18 & 0 & 4 & 4 wire & 8 & 1 & 5 & 5 & 45 \\
\hline 3 & 35 & 4 & 0 & 3 sqr. & 0 & 1 & 4 & 1 & 48 \\
\hline 4 & 13 & 1 & 1 & 0 & 0 & 1 & 29 & 0 & 45 \\
\hline 5 & 14 & 8 & 4 & 1 sqr. & 2 & 0 & 18 & 1 & 48 \\
\hline 6 & 5 & 5 & 1 & 0 & 1 & 0 & 2 & 0 & 14 \\
\hline Total & $\mathbf{9 9}$ & $\mathbf{2 4}$ & $\mathbf{1 4}$ & $\mathbf{5}$ sar., 7 wire & $\mathbf{1 2}$ & $\mathbf{4}$ & $\mathbf{6 0}$ & $\mathbf{1 7}$ & $\mathbf{2 4 2}$ \\
\hline
\end{tabular}




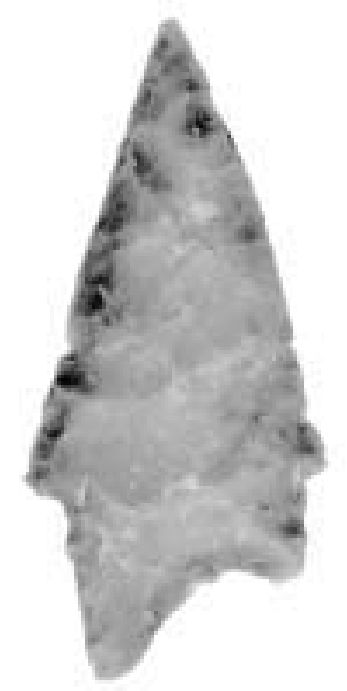

a

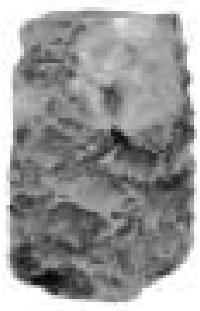

d

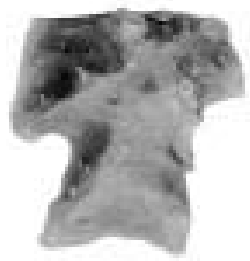

g

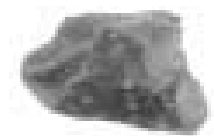

b

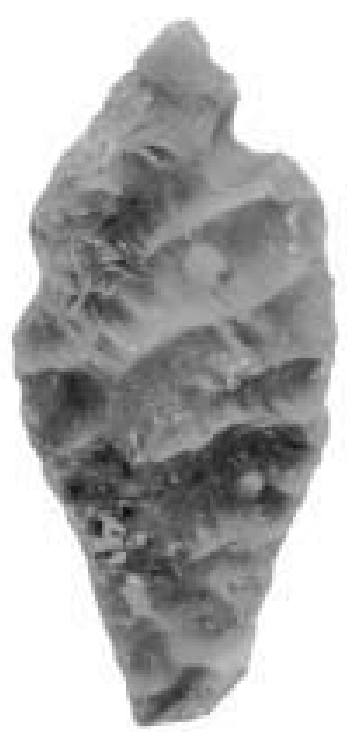

e

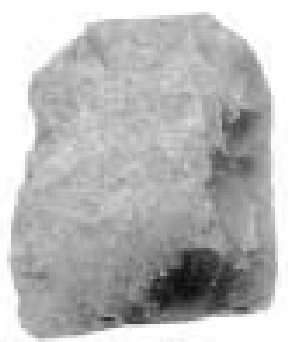

h

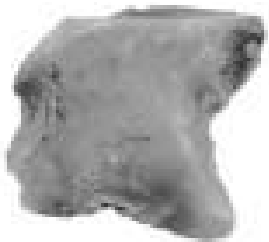

C
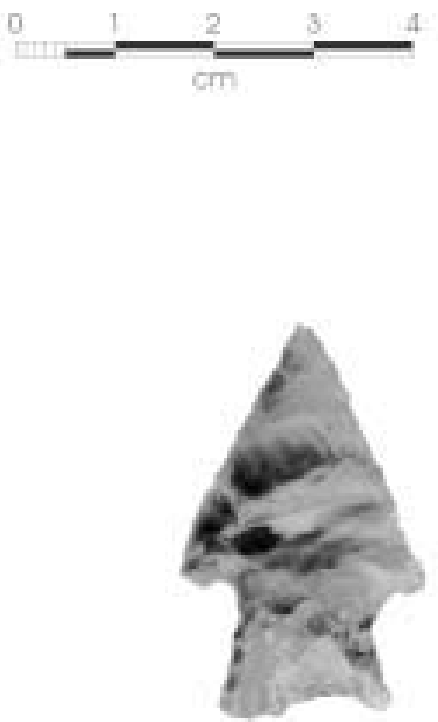

f.

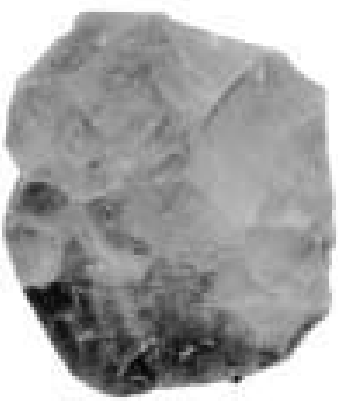

1

Figure 2. Prehistoric artifacts recovered from test units: a) Pedernales point; b) Williams stem fragment; c) Martindale proximal fragment; d) unclassified Paleoindian medial fragment; e) Victoria point; $f-g$ ) early corner notched points; $h-i)$ knife fragments. 


\section{Section 2}

Five shovel tests (STs 13-17) were placed in Section 2 (Figure 1). They revealed a layer of medium reddish-brown (5YR4/6) clay loam soils with yellowishred (5YR5/3) clay mottles and inclusions. STs 13 and 14 contained small quantities of mixed Historic and Modern artifacts and disturbed soils (Tables 3 and 4; Appendix 1). STs 15, 16 and 17 contained no artifacts but revealed intact soils.

Table 3. Artifacts recovered from shovel tests located in Section 2 (STs 13-17)*

\begin{tabular}{|c|c|c|c|c|}
\hline ST\# & $\begin{array}{l}\text { Chipped } \\
\text { Lithic }\end{array}$ & $\begin{array}{l}\text { Misc. } \\
\text { Metal }\end{array}$ & $\begin{array}{l}\text { Misc. } \\
\text { Glass }\end{array}$ & $\begin{array}{l}\text { Constr. } \\
\text { Debris }\end{array}$ \\
\hline 13 & 1 & 1 & 1 & 2 \\
\hline 14 & & 1 & & \\
\hline Totals & 1 & 2 & 1 & 2 \\
\hline
\end{tabular}

${ }^{*}$ no artifact recovery from STs 15,16 , and 17.

Table 4. Breakdown of artifacts from shovel tests in Section 2 (STs 13-17)* by level

\begin{tabular}{|c|c|c|c|c|c|}
\hline Level & $\begin{array}{c}\text { Chipped } \\
\text { Lithic }\end{array}$ & $\begin{array}{l}\text { Misc. } \\
\text { Metal }\end{array}$ & $\begin{array}{l}\text { Misc. } \\
\text { Glass }\end{array}$ & $\begin{array}{l}\text { Constr. } \\
\text { Debris }\end{array}$ & Total \\
\hline 2 & 1 & & 1 & & 2 \\
\hline 3 & & 1 & & & 1 \\
\hline 5 & & 1 & & 1 & 2 \\
\hline 6 & & & & 1 & 1 \\
\hline Total & 1 & 2 & 1 & 2 & 6 \\
\hline
\end{tabular}

${ }^{*}$ no artifact recovery from STs 15, 16, and 17.

\section{Section 3}

Two shovel tests (STs 18-19) were excavated in Section 3. They contained dark yellowish-brown (10YR3/ 4) to yellow (10YR7/6) mottled clay loam and clay soils. The bulk of the materials from ST 18 consists of Modern artifacts (e.g., construction debris) indicative of substantially disturbed stratigraphy (Tables 5 and 6; Appendix 1). ST 19 contained no artifacts.
Table 5. Artifacts recovered from shovel tests located in Section 3 (STs 18-19*)

\begin{tabular}{|c|c|c|c|c|}
\hline ST\# & $\begin{array}{c}\text { Chipped } \\
\text { Lithic }\end{array}$ & $\begin{array}{c}\text { Misc. } \\
\text { Metal }\end{array}$ & $\begin{array}{c}\text { Misc. } \\
\text { Glass }\end{array}$ & $\begin{array}{c}\text { Constr. } \\
\text { Debris }\end{array}$ \\
\hline 18 & 1 & 1 & 1 & 21 \\
\hline Totals & $\mathbf{1}$ & $\mathbf{1}$ & $\mathbf{1}$ & $\mathbf{2 1}$ \\
\hline
\end{tabular}

* ST 19 sterile

Table 6. Breakdown of artifacts from shovel tests in Section 3 (STs 18-19*) by level

\begin{tabular}{|c|c|c|c|c|c|}
\hline Level & $\begin{array}{c}\text { Chipped } \\
\text { Lithic }\end{array}$ & $\begin{array}{c}\text { Misc. } \\
\text { Metal }\end{array}$ & $\begin{array}{c}\text { Misc. } \\
\text { Glass }\end{array}$ & $\begin{array}{c}\text { Constr. } \\
\text { Debris }\end{array}$ & Total \\
\hline 1 & & & & 1 & 1 \\
2 & & & 12 & 12 \\
3 & 1 & 1 & 1 & 8 & 10 \\
4 & & & 1 & $\mathbf{2 1}$ & $\mathbf{2 4}$ \\
\hline Total & $\mathbf{1}$ & $\mathbf{1}$ & $\mathbf{1}$ & $\mathbf{2 1}$ \\
\hline
\end{tabular}

${ }^{*}$ ST 19 sterile 
Table 7. Artifacts recovered from shovel tests located in Section 4 (STs 20-26)

\begin{tabular}{|c|c|c|c|c|c|c|}
\hline ST\# & $\begin{array}{c}\text { Chipped } \\
\text { Lithic }\end{array}$ & $\begin{array}{c}\text { Animal } \\
\text { Bone }\end{array}$ & $\begin{array}{c}\text { Misc. } \\
\text { Metal }\end{array}$ & $\begin{array}{c}\text { Constr. } \\
\text { Debris }\end{array}$ & Other & Total \\
\hline 20 & 4 & & & & & 4 \\
21 & 1 & & & & & 1 \\
22 & 6 & 2 & 4 & 146 & & 158 \\
23 & 13 & 24 & 1 & 3 & 3 FCR & 44 \\
24 & 6 & 1 & 1 & 1 & & 9 \\
25 & 7 & 1 & 8 & 1 & & 17 \\
26 & 3 & & & & & 3 \\
\hline Total & $\mathbf{4 0}$ & $\mathbf{2 8}$ & $\mathbf{1 4}$ & $\mathbf{1 5 1}$ & $\mathbf{3}$ & $\mathbf{2 3 6}$ \\
\hline
\end{tabular}

\section{Section 4}

Seven shovel tests (STs 20-26) were excavated in Section 4. This location provided the richest artifact recovery. The STs contained dark brown (10YR3/3) and black (10YR2/1) clay and clay loam soils. In general, the upper three levels were disturbed due to modern construction, while the lower three levels were relatively intact. Large tree roots present in all shovel test units may have caused artifact displacement.

ST 22-25 contained Historic artifacts intermixed with Prehistoric materials (Table 7). However, miscellaneous metal and construction debris is limited to the upper three levels in these and all other units (Table
$8)$. Therefore, based on the presence of mixed deposits and the soil stratigraphy, the upper portions of this area appeared to be highly disturbed, while deeper levels seemed to be intact.

STs 23 and 24 contained Historic and Prehistoric artifacts. The upper two levels of ST 23 are disturbed while the bottom three levels indicate intact soils. ST 24 encountered a gravel lens and was terminated at the bottom of Level 4 due to a large root.

ST 25 and 26 contained only Prehistoric artifacts and relatively undisturbed soils. At Level 3 in ST 25 a root was encountered and only half of the unit was excavated to Level 5. ST 26 appears to be undisturbed.

Table 8. Breakdown of artifacts from shovel tests in Section 4 (STs 20-26) by level

\begin{tabular}{|c|c|c|c|c|c|c|}
\hline Level & $\begin{array}{c}\text { Chipped } \\
\text { Lithic }\end{array}$ & $\begin{array}{c}\text { Animal } \\
\text { Bone }\end{array}$ & $\begin{array}{c}\text { Misc. } \\
\text { Metal }\end{array}$ & $\begin{array}{c}\text { Constr. } \\
\text { Debris }\end{array}$ & Other & Total \\
\hline 1 & 10 & 1 & 9 & 24 & 0 & 44 \\
2 & 3 & 0 & 2 & 52 & 0 & 57 \\
3 & 9 & 6 & 3 & 75 & 0 & 93 \\
4 & 3 & 10 & 0 & 0 & 0 & 13 \\
5 & 7 & 4 & 0 & 0 & 0 & 11 \\
6 & 8 & 7 & & & 3 & 18 \\
\hline Total & $\mathbf{4 0}$ & $\mathbf{2 8}$ & $\mathbf{1 4}$ & $\mathbf{1 5 1}$ & $\mathbf{3}$ & $\mathbf{2 3 6}$ \\
\hline
\end{tabular}




\section{Backhoe Trenches}

\section{Trench 1}

Eight stratigraphic soil zones were identified in the west wall of BHT 1 (Figure 3). Zone 1 extended from the surface to approximately $12 \mathrm{~cm}$ bs. It contained modern humus and materials (plastic, aluminum can, etc.). Zone 2, comprised of clay with moderate amounts of gravel, extended between 12 and $30 \mathrm{~cm}$ bs. Zone 3 stretched from 30 to $58 \mathrm{~cm}$ bs and contained a gravel lens between $30 \mathrm{~cm}$ and $35 \mathrm{~cm}$ bs. The soil was very dark grayish clay loam (10YR3/1). Cultural materials were not observed in Zones 2 and 3. Zone 4 consisted of a hard-packed dark brown (10YR3/3) soil from approximately 58 to $90 \mathrm{~cm}$ bs. A pocket of charcoal was present between $58 \mathrm{~cm}$ and 62 $\mathrm{cm}$ bs. Zone 5 extended from approximately 90 to 110 $\mathrm{cm}$ bs, and was comprised almost entirely of ash and charcoal. No identifiable cultural materials were present. Zones 6 and 7 are between $107 \mathrm{~cm}$ and 140 $\mathrm{cm}$ bs. Zone 6 intrudes on and into Zone 7. The slope to the San Marcos River bank to the east is visible in these lower zones of the profile. Zone 6 contained yellow (10YR7/6) clay soils with river pebbles, and Zone 7 contained very dark grayish brown (10YR3/ 2 ) clay soils with rusted iron and charcoal scattered throughout. Zone 8 was the last identifiable zone in this profile. It was between 130 to $140 \mathrm{~cm}$ bs in the south half of the profile. It was comprised of black (10YR2/1) clay and was very moist, probably situated just above the water table.

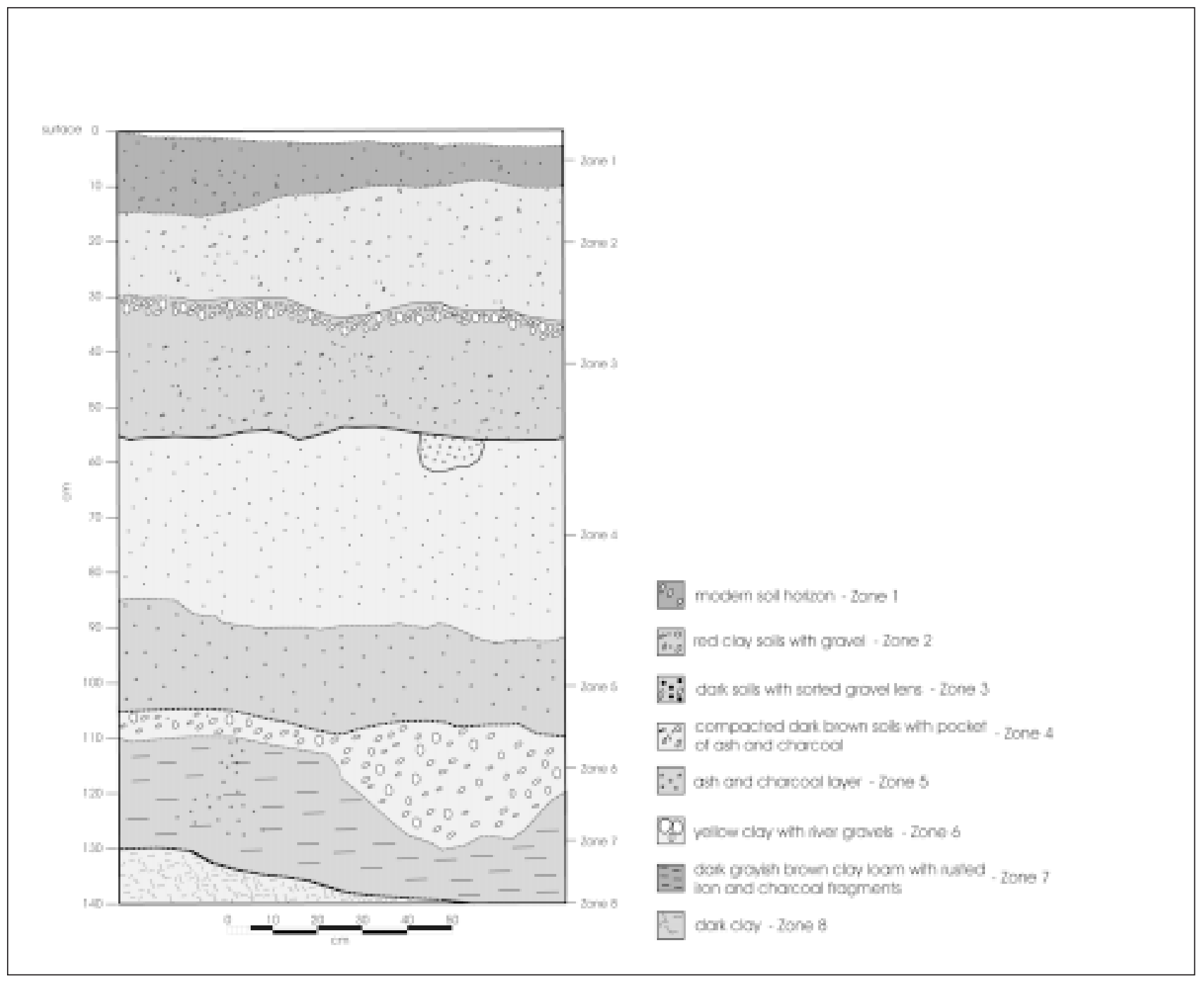

Figure 3. West wall profile of Backhoe Trench 1. 


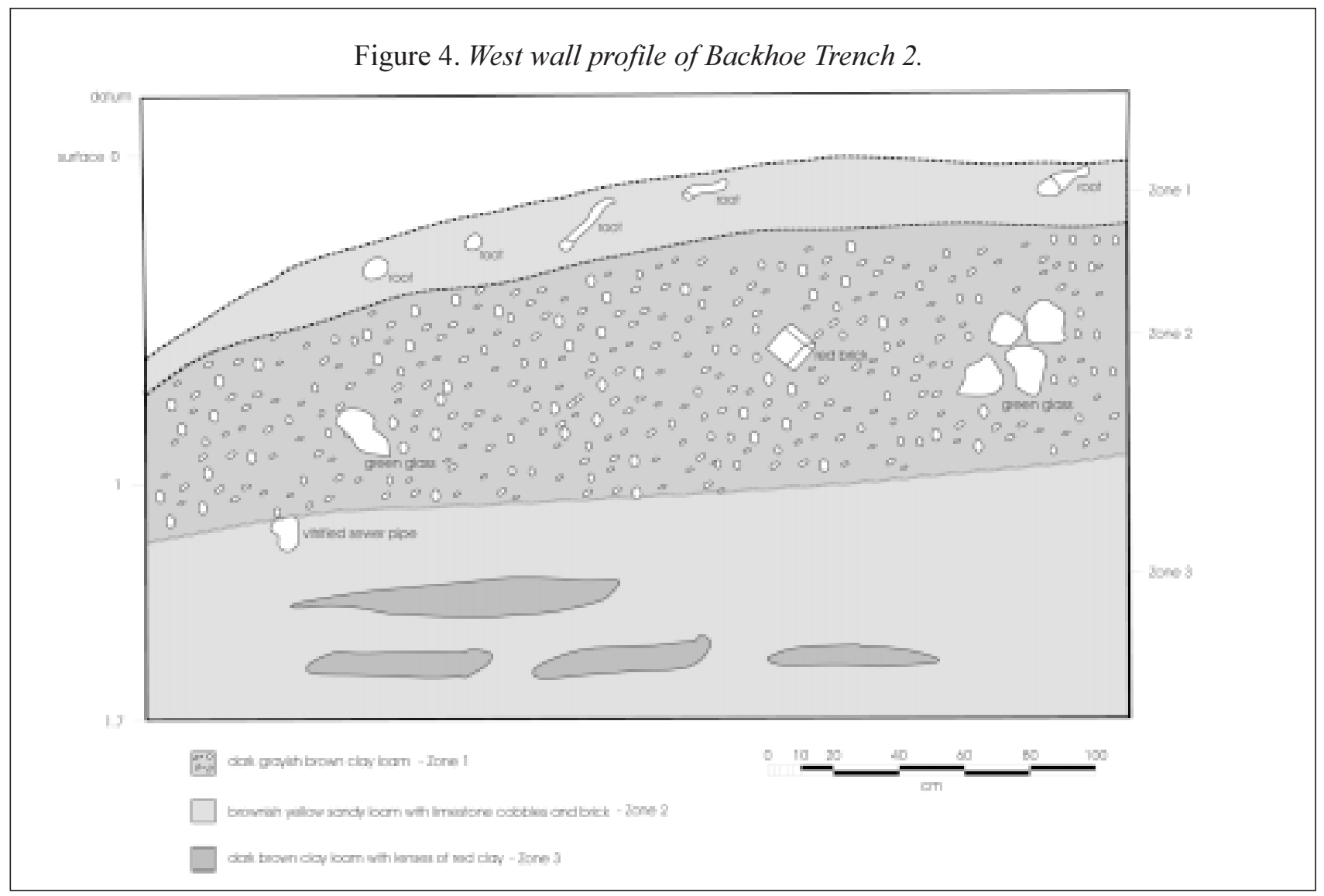

A total of 11 bricks and brick fragments were observed during the backhoe excavation, most were found in the backdirt. Two are D'Hanis bricks, and one is an Alamo brick. D'Hanis bricks have been manufactured in Medina County since 1905 to the present. The Alamo Brick Company was established in San Antonio in the $1880 \mathrm{~s}$. Other construction materials such as iron and cement mortar were also observed in the backdirt and in profile. However, no indication of a structure or intact foundation were observed. This area appears to be highly disturbed by the construction and demolition of historic and modern buildings. The area contained various structures since 1849 , including a mill, utility plant, ice factory, etc., (see Historic Background).

\section{Trench 2}

Three stratigraphic soil zones were identified in the west wall of BHT 2 (Figure 4). Zone 1 consists of topsoil of dark grayish brown (10YR4/2) clay loam, and extends from the surface to $10 \mathrm{~cm}$ bs. Zone 2 is present between 10 and $110 \mathrm{~cm}$ bs. It is comprised of a mixed deposit containing a brownish yellow (10YR6/6) sandy loam with large limestone cobbles, red brick, broken pieces of vitrified sewer pipe, and green bottle glass. The limestone cobbles were loosely packed and possibly used as fill to prevent erosion of the drainage bank. This bank is only a few meters from the existing parking lot south of the Aquatic Biology Building. The vitrified clay sewer pipe was found at approximately $110 \mathrm{~cm}$ bs at the transition between Zones 2 and 3. The pipe appears to have been originally placed on undisturbed soil (Zone 3) and covered with fill. Zone 3 extends from approximately $95 \mathrm{~cm}$ to $170 \mathrm{~cm}$ bs. It is an intact, dark brown (10YR2/2) clay layer with intermittent ribbons or bands of reddish (5YR4/4) clay. No artifacts or disturbances were observed in Zone 3. The eroding, graded bank of the drainage is visible in all three zones, sloping from north to south. 


\section{Utility Trench}

Three geomorphologic zones were noted in the utility trench. Zone 1, the upper $20 \mathrm{~cm}$, consisted of dark reddish (5YR3/2) clay loam. Zone 2 consisted of a 13 $\mathrm{cm}$ thick reddish brown (5YR4/3) clay loam containing both Prehistoric (e.g., core, flakes) and Modern materials (e.g., pebble layer with concrete). Zone 3 appeared to be less disturbed and contained only Prehistoric artifacts (e.g., unmodified debitage and burned limestone).

Several flakes were present on the edge of the trench, apparently unearthed during excavation. These and other artifacts from the backdirt were collected for analysis. A core was found in situ at $70 \mathrm{~cm}$ below the modern surface. Other artifacts include: a Bulverde stem fragment, and edge modified flake, an untypeable dart point distal fragment, 29 items of unmodified debitage, and one animal bone fragment.

\section{Test Unit Excavations}

\section{Test Unit 1}

TU 1 proved to be the least disturbed of all test units and contained a large quantity of archaeological materials. A total of nine arbitrary levels were excavated, and eight geomorphologic zones were identified and described in the south wall profile. The north wall of the unit was located at $13 \mathrm{~cm}$ below datum (bd). Given the slight southward slope of the terrain, the south wall of the unit was at 16 $\mathrm{cm}$ bd. Level 1 was $17 \mathrm{~cm}$ thick and began $13 \mathrm{~cm}$ bd. The remaining levels (2-9) were excavated in $10 \mathrm{~cm}$ levels. TU 1 was excavated to 110 cm bd.

Geomorphologic zones 1-3 were encountered within the first excava- tion level (Level 1; 16-30 cm bd; Figure 5). Excavation Levels 2 and 3 comprised Zone 4. Zone 1 (16-19 $\mathrm{cm}$ bd) was a St. Augustine grass mat. Zone 2 (19-27 $\mathrm{cm}$ bd) was a compacted, very dark grayish brown (10YR3/2) clay loam with gravels and few large limestone cobbles. It had an abrupt wavy irregular and discontinuous lower boundary. Zone $3(27-29 \mathrm{~cm} \mathrm{bd})$ was a brown $(10 \mathrm{YR} 2 / 2)$ clay loam with extremely common 2-30 mm limestone gravels that formed discontinuous lenses. It also had an abrupt wavy to discontinuous lower boundary. Zone 4 (29-49 cm bd) was a slightly compacted grayish-brown (10YR2/2) clay loam with 5 percent small $(1-2 \mathrm{~mm})$ gravels. The zone contained few small shells and had a very abrupt

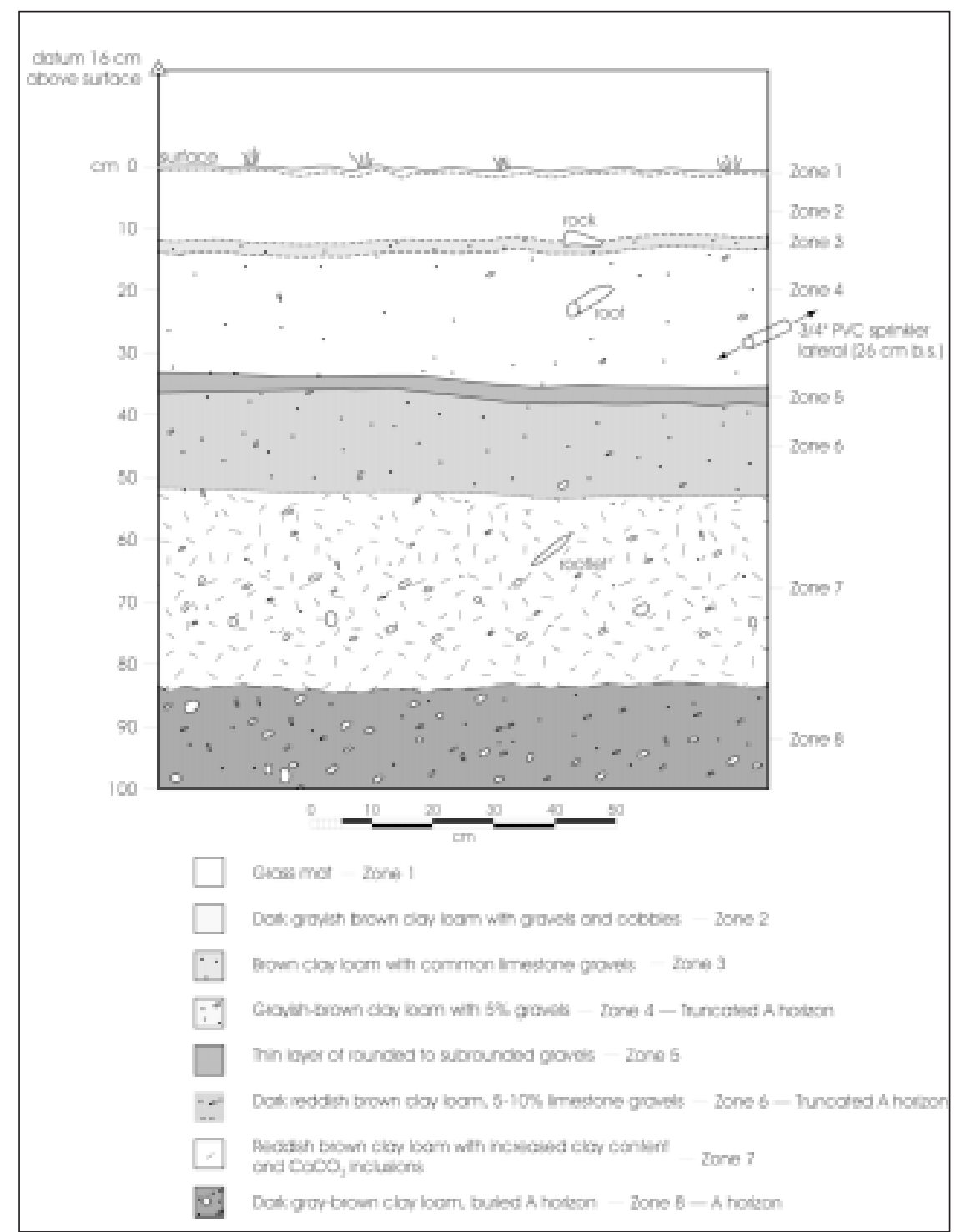

Figure 5. South wall profile of Test Unit 1. 
to wavy discontinuous lower boundary. It represents the first of three truncated A horizons identified in the profile. Zone $5(49-52 \mathrm{~cm} \mathrm{bd})$ was a thin layer of rounded to sub-rounded limestone gravels $(3-20 \mathrm{~mm})$. Gravels comprised from 20-70 percent and varied from clast to matrix supported $(7.5 \mathrm{YR} 3 / 2-3 / 3)$. The zone had a very abrupt to discontinuous lower boundary. Zone $6(52-68 \mathrm{~cm}$ bd) consisted of a dark reddish brown (5YR3/2) clay loam. Small snail shells were very common throughout the deposit and small limestone gravels constituted about 5-10 percent of the zone. Carbonate filaments and earthworm casts were also common. The zone had an abrupt to wavy lower boundary. It represents the second truncated A horizon identified in the profile. Zone 7 (68-99 cm bd) was a reddish brown (5YR4/4) clay loam with higher clay content than the previous zone. The matrix in Zone 7 had a moderate to strong angular to sub-angular blocky structure. Small calcium carbonate pebbles $(5-30 \mathrm{~mm})$ were most common in the middle of the zone. The zone had a smooth wavy and clear lower boundary. Zone $8(99-110+\mathrm{cm} \mathrm{bd})$ is the third and deepest A horizon. It is a very dark grayish brown (10YR3/2) clay loam. It had a medium (5 cm or less) to fine, moderate strength, sub-angular blocky structure. Small (1-2 mm) limestone gravels were present in the zone and snail shells were common throughout, while worm casts were rare. The zone continued below the bottom of the excavation level.

Organic matter from this soil (Test Unit 1, Zone 8) was submitted for radiocarbon dating to Beta Analytic Incorporated. The resulting estimate of $1060 \pm 70 \mathrm{BP}$ (Beta-132889, ${ }^{13} \mathrm{C}=-20.1 \%$ ) reflects a serious contamination problem with modern organic matter. Three large, bald cypress trees (Taxodium distichum) grow near these units and their dense subsurface roots are the likely contaminant. It is possible that microscopic rootlets were not completely extracted in the sample preparation process, and this may have caused contamination in the older organic carbon within the soil.
A large number of artifacts were recovered from the unit. The majority consist of unmodified lithic debitage $(n=658)$ and construction materials (i.e., brick fragments; $n=368$; Table 9). A number of chipped lithic tools $(n=22)$ consisting of complete and broken bifaces, projectile points, and unifaces have also been recovered.

The top three excavation levels (Levels 1-3, 16-50 $\mathrm{cm} \mathrm{bd}$ ) had been disturbed by previous parking lot construction, sprinkler system installation, and landscaping activities (i.e., sod placement). Numerous brick fragments and a small number of metal artifacts came from the top two levels and are indicative of recent disturbance (Table 10, Appendix 2).

Level 1 also contained two fragments of human cranial bone which refit along an old break. Given the close proximity of the location to two known Prehistoric burials (Garber and Glassman 1992), during the monitoring of the pipeline trench the soils were screened for human remains (see Pipeline Monitoring). No other evidence of human skeletal remains was found during this testing. Although no obvious soil disturbances were noted in Level $4(50-60 \mathrm{~cm}$ bd), the recovery of a whiteware ceramic fragment from Level $5(60-70 \mathrm{~cm} \mathrm{bd})$ suggests that disturbed soils may extend to $70 \mathrm{~cm}$ bd. Levels 6 through 9 contained no visible disturbances.

Other notable finds from the unit include:

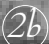

A Late Archaic Williams stem fragment from Level 7 (80-90 cm bd; Figure 2b);

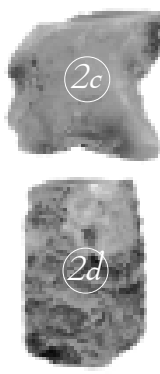

A proximal Early Archaic Martindale fragment from Level 8 (90-100 cm bd; (Figure $2 \mathrm{c})$; and

The mid-section of an untypeable late Paleoindian point from the same level (Figure 2d).

Table 9. Artifacts recovered from test units

\begin{tabular}{|c|c|c|c|c|c|c|c|c|c|c|c|}
\hline & Unmodified & Lithic & Animal & Misc. & Misc. & & Constr. & Snails/Mussell & & & \\
\hline Unit & Debitage & Tools & Bone & Metal & Glass & Ceramics & Debris & Shell & FCR & Other & Totals \\
\hline 1 & 658 & 22 & 14 & 14 & 0 & 1 & 368 & 101 & 9 & 1 seed, 2 skull frags. & 1190 \\
\hline 2 & 217 & 14 & 6 & 19 & 0 & & 2 & 3 & 43 & & 304 \\
\hline 3 & 435 & 13 & 18 & 0 & 4 & & & 57 & 65 & 4 unid. mat., & 596 \\
\hline Totals & 1310 & 49 & 38 & 33 & 4 & 1 & 370 & 161 & 117 & 7 & 2090 \\
\hline
\end{tabular}


Table 10. Breakdown of artifacts from all test units combined by level

\begin{tabular}{|c|c|c|c|c|c|c|c|c|c|c|c|c|}
\hline & & Unmodified & Lithic & Animal & Misc. & Misc. & European & Constr. & Snails/Mussell & & & \\
\hline Level & Depth & Debitage & Tools & Bone & Metal & Glass & Ceramics & Debris & Shell & FCR & Other & Totals \\
\hline 1 & $0-30$ & 34 & 4 & 4 & 26 & 2 & & 364 & & 6 & 2 unid., mat.; 2 skull frags. & 444 \\
\hline 2 & $30-40$ & 88 & 4 & 10 & 7 & & & 6 & & 23 & 2 unid., mat. & 140 \\
\hline 3 & $40-50$ & 166 & 3 & 3 & & & & & 8 & 13 & & 193 \\
\hline 4 & $50-60$ & 235 & 8 & 9 & & 2 & & & 5 & 21 & & 280 \\
\hline 5 & $60-70$ & 196 & 11 & & & & 1 & & & 25 & & 233 \\
\hline 6 & $70-80$ & 179 & 2 & 1 & & & & & 94 & 18 & & 294 \\
\hline 7 & $80-90$ & 188 & 7 & & & & & & 35 & 2 & & 232 \\
\hline 8 & $90-100$ & 149 & 6 & & & & & & 13 & & & 168 \\
\hline 9 & $100-110$ & 75 & 4 & 11 & & & & & 6 & 9 & 1 seed & 106 \\
\hline Totals & & 1310 & 49 & 38 & 33 & 4 & 1 & 370 & 161 & 117 & 7 & 2090 \\
\hline
\end{tabular}

The recovery of the Late Archaic Williams stem fragment in the bottom of geomorphologic Zone 7 (68-99 $\mathrm{cm} \mathrm{bd),} \mathrm{the} \mathrm{transition} \mathrm{from} \mathrm{the} \mathrm{upper} \mathrm{matrix} \mathrm{to} \mathrm{the}$ buried A horizon, suggests some degree of disturbance given that it is only $10 \mathrm{~cm}$ above an Early Archaic Martindale and an untypeable late Paleoindian point. However, no soil disturbances were noted at this depth to support or discount this possibility.

\section{Test Unit 2}

This unit was located approximately 2 meters from the top edge of the artesian spring (Figure 1). TU 2 was excavated to a depth of $70 \mathrm{~cm}$ bs $(87 \mathrm{~cm} \mathrm{bd})$ before it was terminated due to multiple large roots impeding progress. The northwest and northeast corners of the unit were located at $13 \mathrm{~cm}$ bd. The unit sloped to the south, so that its southwestern and southeastern corners were located 17 $\mathrm{cm}$ below datum. The elevation of the excavation levels and south wall profile were measured from the center of the unit's northern wall.

Five geomorphologic zones were identified in the south wall profile (Figure 6). Zone 1 (17-21 cm bd) of the south wall consisted of a St. Augustine grass mat. Zone 2 $(21-25 \mathrm{~cm} \mathrm{bd})$ was a very dark grayish brown (10YR3/2) layer of slightly compacted gravel. The gravels probably represent the remnants of a previous parking lot. The zone had a wavy, discontinuous lower boundary. Zone 3 (25-52 $\mathrm{cm}$ bd) contained a very dark grayish-brown (10YR3/ $2)$, slightly compacted clay loam with earthworm casts, rootlets, and roots. Zone $4(52-67 \mathrm{~cm}$ bd) contained a dark yellowish brown (10YR3/4), blocky clay loam with common limestone gravels $(3-5 \mathrm{~mm})$ and calcium carbonates $(5 \%)$. Its lower boundary was wavy and discontinuous. Zone $5(67-90 \mathrm{~cm}$ bd) was comprised of a dark yellowish brown (10YR4/6) clay loam containing common calcium carbonates, rootlets, and

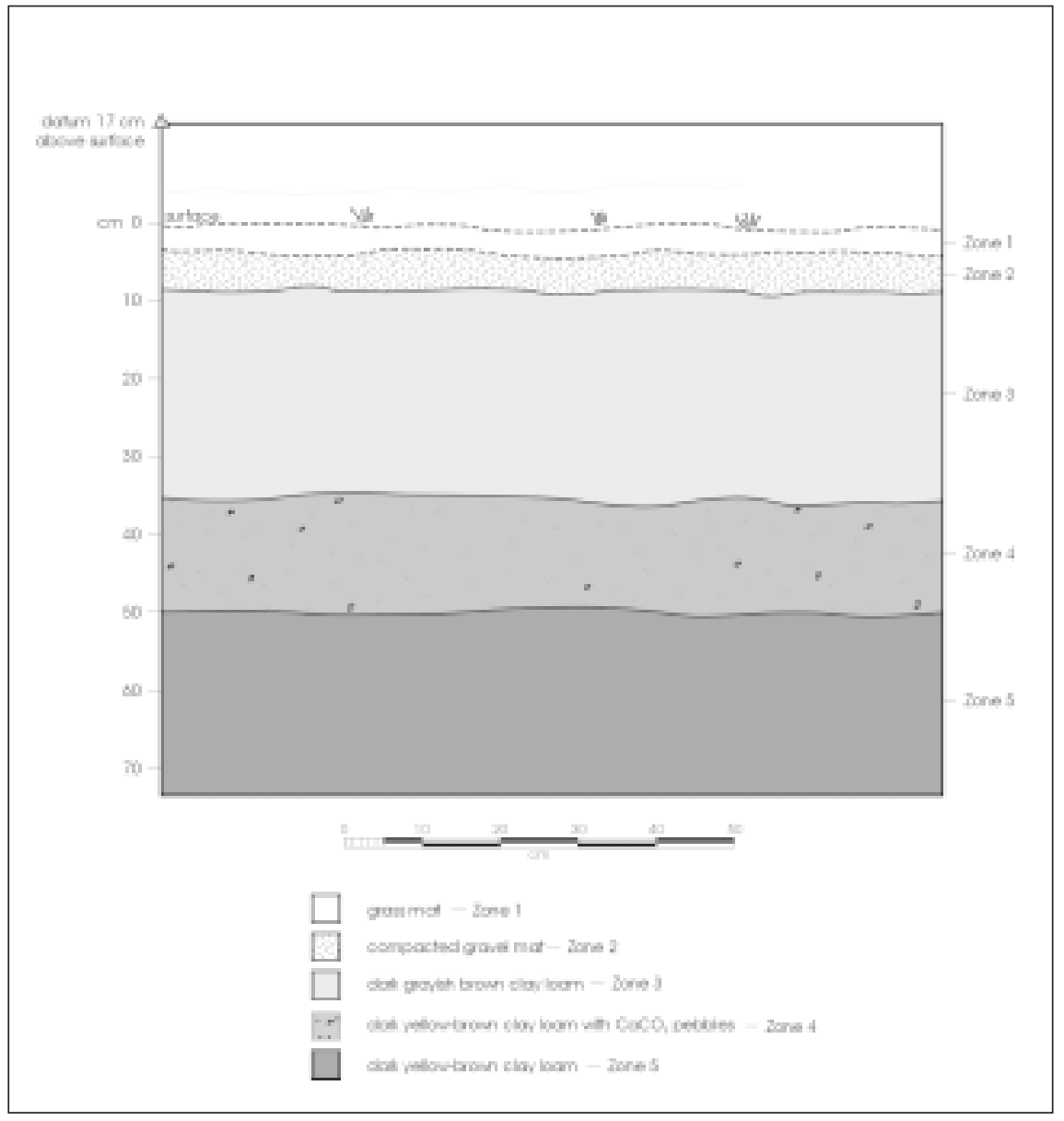

Figure 6. South wall profile of Test Unit 2. 
roots (3-20 $\mathrm{cm}$ in diameter) and 5\% limestone gravels and carbonate filaments. No lower boundary existed because the unit was terminated at this level.

Large to moderate sized roots were prevalent throughout the first six levels (13-80 cm bd). Brick fragments, soda caps, and rusted metal pieces attest to the anthropogenic disturbances of Level $1(13-30 \mathrm{~cm} \mathrm{bd}$; Table 9, 10; Appendix 2). Three unidentified metal pieces were recovered from Level 2, suggesting that modern disturbances extend to at least a depth of 40 $\mathrm{cm}$ bd. Levels 2-7 contained moderate numbers of unmodified debitage, and small numbers of chipped lithic tools, including a core (Level 2, 30-40 cm bd), an end scraper (Level 2), and a number of early to late reduction stage bifaces (Appendix 2). Debitage counts appeared to peak between $50-70 \mathrm{~cm} \mathrm{bd}$, decreasing with depth thereafter (Appendix 2). Although no obvious signs of anthropogenic disturbances were noted below Level 2, the large number of roots found throughout the unit may have significantly bioturbated the deposits.

\section{Test Unit 3}

The flat surface of TU 3 was located $13 \mathrm{~cm}$ below datum. It was excavated in eight levels, with the first level being $17 \mathrm{~cm}$ thick and all others measuring $10 \mathrm{~cm}$ in thickness. Moderate to small roots were present throughout the excavation unit and caused the halting of the excavation at 100 $\mathrm{cm}$ bd.

Four geomorphologic zones were identified in the south wall profile of the unit (Figure 7). Zone 1 (13-22 cm bd) contained the St. Augustine grass mat. Zone 2 (22$45 \mathrm{~cm}$ bd) was a compact, blocky dark grayish brown (10YR3/2) clay loam. It contained common limestone gravels, small to medium roots, one large root $(20 \mathrm{~cm}$ diameter), and a discontinuousirregular wavy lower boundary. Zone 3 (45-84 cm bd) was a dark yellowish brown (10YR4/6) clay loam exhibiting common calcium carbonate inclusion, limestone gravels (1-5 mm), scattered limestone cobbles (5\%), few rootlets, and one large root ( $8 \mathrm{~cm}$ diameter). The lower boundary was a mostly smooth-somewhat wavy, clear boundary. Zone 4 (84-98 cm bd) was a very dark grayish brown (10YR3/2) clay loam with common snail shells, and few limestone gravels. This zone is equivalent to the buried A horizon paleosol observed in Unit 1. The lower boundary of the zone was not defined as the unit was terminated at a depth of $100 \mathrm{~cm} \mathrm{bd}$.

Lithic debitage was present in all levels although two peaks can be clearly noted at $40-50 \mathrm{~cm}$ bd and $80-90$ cm bd (Table 9, 10; Appendix 2). Faunal remains and/ or fire cracked rock were present in Levels 5, 6, 7, and 8. Two "Early Corner-Notched" or "Split Stem" points were recovered in Levels $3(40-50 \mathrm{~cm}$ bd) and 4 (50-60 cm bd; Figure 2e-f). They show affinities to the Martindale-Bandy point types that date to the Early Archaic (Turner and Hester 1993). It is possible that

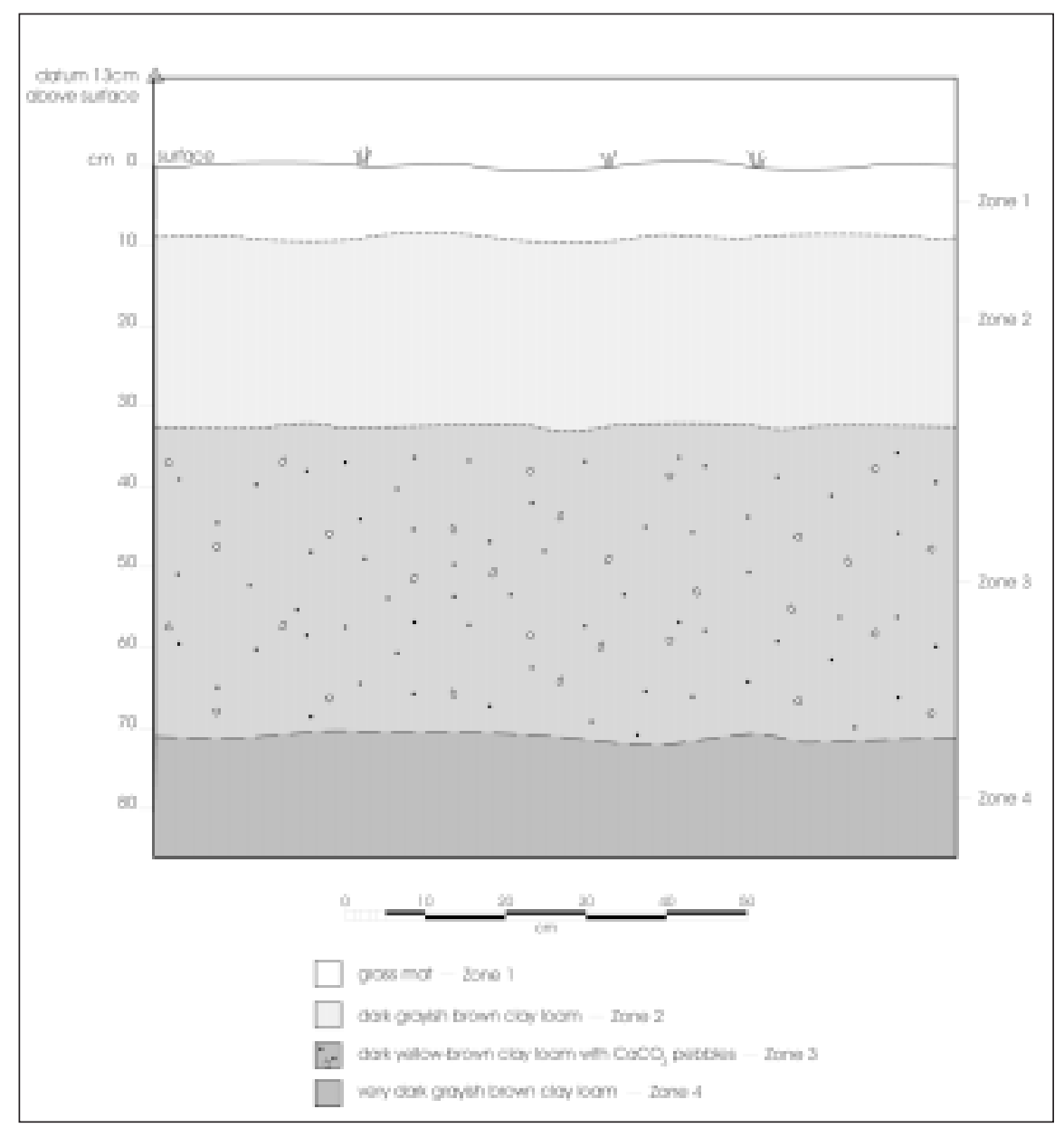

Figure 7. South wall profile of Test Unit 3. 
these points are associated with the first peak in debitage, which suggests that the second deeper peak may represent an even older occupation zone. Unfortunately, the recovery of fragments $(n=2)$ of clear and brown glass at $60-70 \mathrm{~cm}$ bd (Appendix 2) suggests some degree of disturbance. The presence of roots throughout the unit raises the possibility that the disturbance may be due to bioturbation alone.

\section{Pipeline Monitoring}

Monitoring of the pipeline trench excavation identified a variety of cultural materials including recent trash as well as Prehistoric artifacts. Flakes and burned rock were encountered throughout the trench. Other Prehistoric artifacts included two bifaces located next to the sidewalk. The close proximity of these artifacts to the sidewalk suggests that they were most likely redeposited into a disturbed context. A nearly complete Pedernales dart point (Figure 2a) and a number of unmodified debitage were recovered from a backdirt pile excavated from the trench.

\section{Bore Pit Inspection}

Bore Pit 1 was examined on July 7th, several days after it had been excavated. It was photographed, and profiles of the exposed west wall and a small section of the northeast corner were sketched. A small number of artifacts were collected in situ within the profile. The large amount of backdirt from the bore pit excavation was also given an cursory examination for artifacts. No artifacts were found.

The profile of the west wall of the bore pit contained 6 geomorphologic zones:

\section{Zone 1 (0-20 cm bs);} Contained grass mat, roots and rootlets, dark brown, mottled clay loam with snail shells;

\section{Zone 2 (20-25 cm bs);} Reddish brown clay containing gravels, roots, river pebbles, and a wavy lower boundary;

Zone 3 (25-35 cm bs); Very moist dark brown clay loam, with abundant ash, charcoal, and slag;

\section{Zone 4 (35-55 cm bs);}

Consisted of a mottled yellow clay loam, with roots, large limestone cobbles and a wavy lower boundary;

\section{Zone 5 (55-110 cm bs);}

Made up of heavily mottled dark brown clay loam and contained large limestone cobbles;

Zone 6 (110-300 cm bs);

Contained a yellowish-red (5YR4/6) clay loam with few roots and snails, and common calcium carbonate inclusions.

This clay zone is probably the same soil zone described by Shiner (1983) as the principal cultural materialbearing deposit on the banks of the San Marcos River.

Two flakes and a projectile point were collected from an undisturbed section of the west wall of the bore pit at a depth of $170 \mathrm{~cm}$ bs.

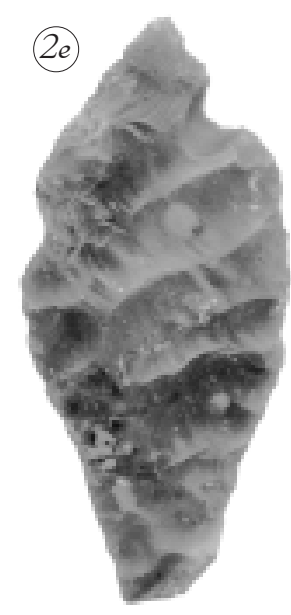

The dart point is a narrow stemmed but broad bladed specimen (Figure 2e) that fits within the Victoria type defined by Kelly (1983:20) based on Angostura-like specimens from the Brom Cooper Collection (McMillan County). Birmingham and Hester (1976:18, Figure 4d) identified similar "lanceolate weakly shouldered points" in the Johnston-Heller site (41VT15) in Victoria County. A number of Victoria points also were recovered from the Wilson-Leonard site from deposits dating between 8,400-7,900 BP (Bousman 1999, personal communication). These specimens are identified as Thrall points by Collins. The specimen is also roughly similar to the Orchard type defined by Mitchell (1976) based on a limited number of specimens.

The stem edges of the specimen are lightly ground and subtle alternate left beveling is evident on its edges. Its narrow base (approx. $12 \mathrm{~mm}$ ) is slightly concave $(1.2 \mathrm{~mm})$ and moderately ground. It is missing one ear. The stem gradually widens beginning immediately at the base and the neck is $29 \mathrm{~mm}$ wide. The blade is $33 \mathrm{~mm}$ wide and maximum width is 43 $\mathrm{mm}$ forward of the base. The point has been heavily resharpened and measures $72 \mathrm{~mm}$ in maximum length. It is $7.8 \mathrm{~mm}$ thick at its maximum immediately above the neck. 


\section{Artifact Analysis}

Because the artifacts recovered from shovel tests, backhoe trenches, and the monitoring of the pipeline trench do not represent a cohesive analytical assemblage, and many also are derived from highly disturbed portions of the project area, they will not be analyzed in detail. The artifacts recovered from the shovel tests are presented in Appendix 1. This section describes only the chipped lithic artifacts obtained from test unit excavations. The fragments of bone, metal, glass, plastics, and bricks recovered from the TUs are clearly of modern origin and are not discussed. The Prehistoric artifacts consisted of chipped stone tools and debitage.

The test unit excavations produced 1359 chipped stone artifacts. This collection consists of 6 projectile points, 4 knives, 17 scrapers, 1 graver, 18 miscellaneous bifaces, 2 miscellaneous unifaces, 1 core, and 1310 unmodified lithic debitage. The miscellaneous bifaces and unifaces contain artifacts that could not be assigned to functional categories.

\section{Projectile Points}

Although the smallest class of artifacts recovered from the test units, the points provide chronological information that other artifact types cannot. A total of 6 projectile points were recovered from the test units.

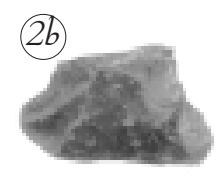

The youngest of the points recovered from TU 1 is the stem fragment of a Williams point (Figure 2b). The expanding stem $(19 \mathrm{~mm})$, straight based fragment has a rather thick $(7.5 \mathrm{~mm})$ and narrow $(13 \mathrm{~mm})$ neck typical of these Late Archaic points. It was recovered in Level $7(80-90 \mathrm{~cm} \mathrm{bs})$.

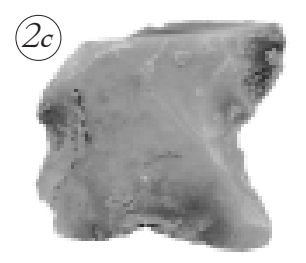

The second of the dart points recovered from TU 1 is a Martindale preform proximal fragment (Figure 2c). It has a broad expanding stem and a recurved base. The specimen is made on a heat treated fine-grained chert flake blank. The stem of the specimen had already been roughed out when it was broken in manufacture. It has a 19 $\mathrm{mm}$ wide neck, and the base is $2 \mathrm{~mm}$ deep. The flake blank is $7 \mathrm{~mm}$ thick at the break.
TU 1 also produced the oldest of the points recovered during testing. This medial blade fragment, recovered from Level 8 (90-100 cm bs), has the parallel oblique flaking and relatively narrow (17-19 mm), strongly biconvex and thick $(6 \mathrm{~mm})$

blade typical of late Paleoindian points such as the Angostura type (Figure 2d). The cause of break could not be determined although the point appears to have been a fully functional specimen. An additional

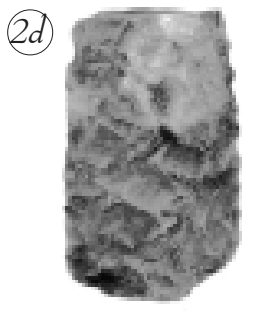
untypeable medial dart point fragment (not shown) also was recovered from Level $1(13-30 \mathrm{~cm} \mathrm{bs})$ of the unit. It is made of the same gray fine-grained chert as the Martindale preform. The specimen is heavily heat shattered.

Two additional dart points, a complete specimen and a proximal fragment, have been recovered from the test excavations. Both come from TU 3 and are examples of what Hester (1971:71-73) identified as "Early Corner Notched" points at the La Jita Site in Uvalde County. Both points have slight to moderately expanding stems formed by corner notching. Both bases are concave and somewhat reminiscent of the recurved bases of Martindale points. The complete point is $40 \mathrm{~mm}$ in length,

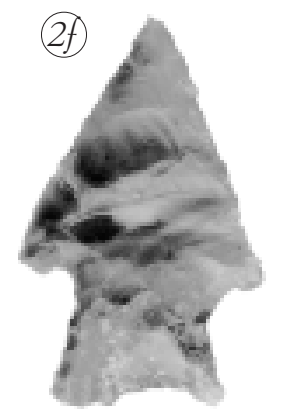
with the stem measuring $14 \mathrm{~mm}$ (Figure 2f). It has a $25 \mathrm{~mm}$ wide blade, with missing barbs, a neck width of $14 \mathrm{~mm}$ and a stem width of $18 \mathrm{~mm}$. The base is 3 $\mathrm{mm}$ deep and the point is $6 \mathrm{~mm}$ thick.

The proximal fragment is broken above the neck and is missing a shoulder and a corner of the stem (Figure $2 \mathrm{~g})$. These breaks as well as the failure of the blade occurred during use. Only two complete measurements can be recorded on the specimen. It has a $13 \mathrm{~mm}$ wide neck and a maximum thickness of $7 \mathrm{~mm}$. The complete specimen

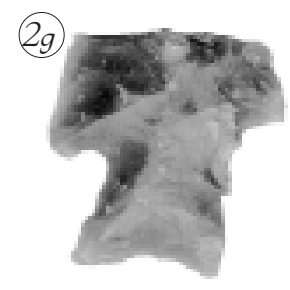
was recovered in Level 4 (40$50 \mathrm{~cm} \mathrm{bs}, 53 \mathrm{~cm} \mathrm{bd}$ ), the proximal fragment comes from Level 3 (30-40 cm bs, $46-50 \mathrm{~cm} \mathrm{bd})$. 


\section{Knives}

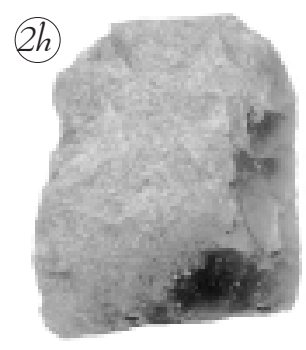

Based on a combination of use and haft wear, four artifacts have been identified as knives. Two are proximal biface fragments (Figure $2 \mathrm{~h}-\mathrm{i}$ ), one is a minimally retouched blade fragment, and the fourth is an expedient tool. The presence of haft wear, identified under 40x magnification, on both late reduction stage specimens suggests that they were hafted and used as knives. They appear to be fragments of triangular knives. Both come from Level 4 (50-60 cm bd) of TUs 1 and 2, respectively. The third specimen is the distal fragment of a large secondary blade. It was recovered in Level $5(60-70 \mathrm{~cm}$ bd) of TU 2 . It is heavily retouched on its dorsal face and some retouch is also evident on its ventral surface along the pointed distal tip. The specimen appears to have been broken in the process of edge rejuvenation. The final specimen is a small tertiary flake fragment with a scalloped edge identical to use wear generated from cutting and/or sawing. No retouch, other than that derived from use, is evident on the working edge of this expedient specimen.

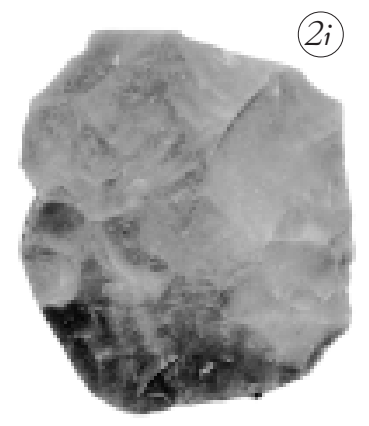

\section{Scrapers}

On the basis of the presence/absence of use wear, established under low power magnification (40x), 17 specimens are identified as scrapers. Of these, five $(29 \%)$ have minimally or extensively retouched working edges, and $12(71 \%)$ are expedient scrapers with micro-flaking resulting only from use. Based on the location of the working edge, three of the retouched specimens are end and two are side scrapers. One of the three end scrapers, a heavily patinated flake from Level 5 of TU 2, has a deeply notched spoke-shavelike working edge. Of the 12 expedient scrapers only five are complete. Three of these are side scrapers and the remaining two are end scrapers. The remaining seven specimens appear to represent fragments of side scrapers on small to medium sized tertiary flakes. However, the majority of these fragments are so small that it is difficult to establish with certainty whether they represent fragments of side scrapers, combination end/side scrapers, or end scrapers.

\section{Graver}

A single secondary flake fragment with a pointed distal end is classified as a graver. The pointed working edge has been unifacially retouched for a distance of $12-15 \mathrm{~mm}$ along its edges. Two micro-burin flake scars on the working tip are indicative of resharpening and moderate step-fracturing suggests extensive use and/ or the working of hard materials.

\section{Miscellaneous Bifaces}

A total of 18 nonprojectile point bifacially flaked artifacts were recovered during the excavation of the test units. One of the specimens is complete while the remaining bifaces are fragmentary.

They consist of five proximal, one medial, five distal, and six indeterminate edge fragments. The complete specimen is a primary flake with bifacial flaking along one edge. It was recovered in Level $7(80-90 \mathrm{~cm}$ bd) of TU 3. It represents the very early stages of biface manufacture. The reduction may have been aborted due to the small size and coarseness of the blank. Four of the remaining fragmentary bifaces are early reduction stage specimens, eight are middle reduction stage, and the remaining five are late reduction stage manufacture failures. All are made on locally available finegrained chert.

\section{Miscellaneous Unifaces}

Artifacts that are either too small to identify microwear or do not exhibit use wear but are unifacially flaked are classified in this category. Two items are in this group. Only one of the two is complete, it was recovered in Level $3(40-50 \mathrm{~cm} \mathrm{bd})$ of TU 3. It is a short secondary flake with unifacial retouch along the distal margin. The steepness ( 89 degrees) of the retouch suggests that the thickness of the flake may have presented difficulties in the proper reduction of the 
flake blank and led to the discard of this manufacture failed uniface. The incomplete specimen is a tertiary medial flake fragment with a serrated lateral edge. It was recovered in Level 9 (100-110 cm bd) of TU 1. The break morphology suggests that it was the manufacture of one of the notches that caused the failure of the flake blank. It is possible that the specimen was intended as a minimally retouched knife. No use wear is evident on the specimen.

\section{Core}

A single multi-directional core has been recovered during the excavation. It comes from Level 2 of TU 2. It has 17 flake removals scars and appears to be exhausted. It measures $57 \times 48 \times 30 \mathrm{~mm}$ in maximum dimensions.

\section{Unmodified Debitage}

A total of 1310 unmodified lithic debitage was recovered from the three TUs. The majority came from TU 1 followed by TU 3 . The vertical distribution of debitage in TU 1 suggests three peaks, while two peaks can be discerned in TU 3 (Figure 8). A single peak in debitage numbers is evident in TU 2. It is tempting to suggest that these peaks represent distinct archaeological components. However, it was noted in the discussion of the stratigraphy of the three units that anthropogenic and/or biogenic disturbances may have affected the cultural materials in Levels 1-5 (13-70 $\mathrm{cm}$ bd) in TU 1, Levels $1-2(13-40 \mathrm{~cm} \mathrm{bd})$ and possibly deeper in TU 2, and Levels 1-5 (10$70 \mathrm{~cm} \mathrm{bd}$ ) in TU 3. On the other hand, a distinct buried A horizon was noted beginning at a depth of $84-98 \mathrm{~cm}$ bd in TU 3, and 99-110 $\mathrm{cm}$ bd in TU 1, and truncated A horizons were noted in Zone 4 (29-49 $\mathrm{cm} \mathrm{bd})$ and Zone 6 (52$68 \mathrm{~cm}$ bd) in TU 1 .

These patterns suggest that the only undisturbed deposits and therefore behaviorally associated artifacts are contained in Levels 8-9 (90-110 cm bd) in TUs 1 and 3. Unfortunately, only 224 debitage were recovered from these four levels making meaningful analysis of such a small sample difficult.
A preliminary analysis of this debitage indicated that a variety of flakes are present including flakes derived from all stages of biface manufacture, uniface and biface resharpening flakes, and debitage derived from core reduction and core/platform preparation. Both hard hammer and soft hammer flakes are present in the collection. The same range of debitage appears to be contained in the overlying levels. However, due to the small sample sizes present in the deeper levels, it cannot be established whether these similarities represent behavioral continuity or the product of intermixing of distinct components. A more meaningful analysis of technological trends awaits the collection of larger samples of debitage from undisturbed contexts of the site.

\section{Analysis Units}

The different geomorphologic zones in the three excavation units did not show any clear correspondences along which to divide the deposits and cultural materials into analysis units. Therefore, it was decided to investigate the mean size of unmodified debitage by excavation level to discern any patterning. It is assumed that debitage collections derived from the downward movement of artifacts from living surfaces should be smaller in overall sample size, as well as in mean average size compared to collections derived from the actual living surfaces themselves. That is, the smaller the size of the debitage, the deeper it can move below the original living surface on which it has been deposited.

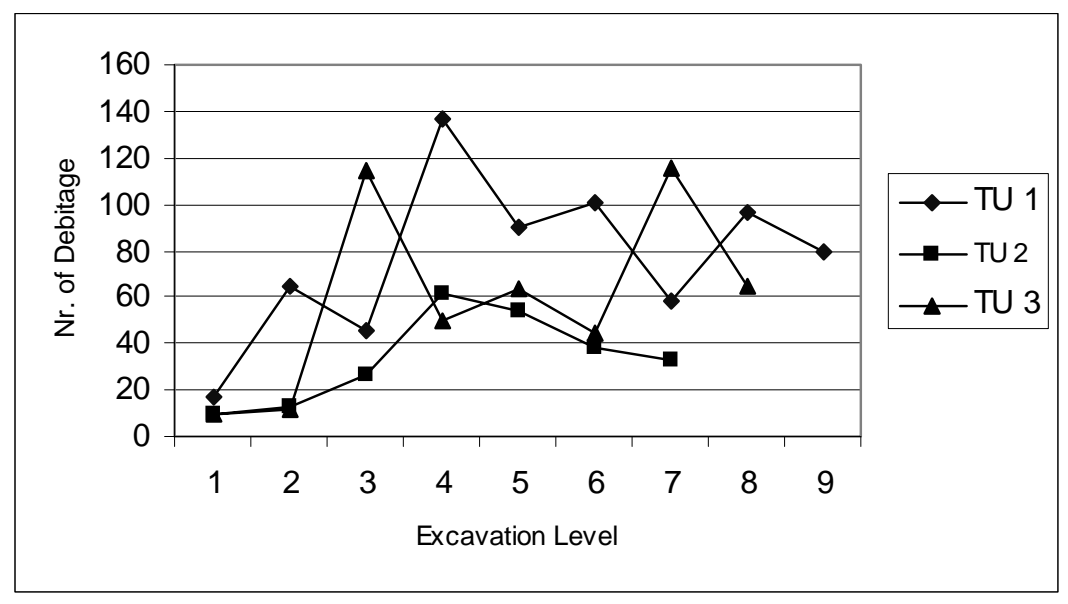

Figure 8. Distribution of debitage quantities within test units by excavation level. 
Table 11. Breakdown of unmodified debitage size characteristics by level within the three test units

\begin{tabular}{|c|c|c|c|c|c|c|c|c|c|}
\hline & Level 1 & Level 2 & Level 3 & Level 4 & Level 5 & Level 6 & Level 7 & Level 8 & Level 9 \\
\hline \multicolumn{10}{|l|}{ Test Unit 1} \\
\hline Mean size $(\mathrm{mm})$ & 21.7 & 18.5 & 21.4 & 18.4 & 21.2 & 17.7 & 20.8 & 19.2 & 17.7 \\
\hline n & 15 & 63 & 42 & 131 & 87 & 100 & 55 & 90 & 75 \\
\hline$\%$ in $1-20 \mathrm{~mm}$ & 47 & 73 & 57 & 72 & 57 & 73 & 62 & 68 & 76 \\
\hline \multicolumn{10}{|l|}{ Test Unit 2} \\
\hline Mean size $(\mathrm{mm})$ & 47.3 & 21.1 & 19.9 & 19.9 & 21.5 & 19.3 & 17.7 & & \\
\hline n & 10 & 13 & 25 & 56 & 49 & 37 & 27 & & \\
\hline$\%$ in $1-20 \mathrm{~mm}$ & 60 & 31 & 48 & 50 & 37 & 41 & 63 & & \\
\hline \multicolumn{10}{|l|}{ Test Unit 3} \\
\hline Mean size $(\mathrm{mm})$ & 29.4 & 24.2 & 18.3 & 21.5 & 19.3 & 20.0 & 19.9 & 19.2 & \\
\hline n & 9 & 12 & 99 & 48 & 60 & 42 & 106 & 59 & \\
\hline$\%$ in $1-20 \mathrm{~mm}$ & & & 72 & 54 & 73 & 64 & 59 & 66 & \\
\hline
\end{tabular}

Since debitage was grouped into $10 \mathrm{~mm}$ size classes, it was decided to use the midpoint of each size class as the mean of the flakes within the size class (i.e., 5 $\mathrm{mm}, 15 \mathrm{~mm}, 25 \mathrm{~mm}$ for size classes 1-10 mm, 11-20 $\mathrm{mm}$, and 21-30 $\mathrm{mm}$ respectively). To derive the mean size of the debitage from a level, the number of flakes within each size class was multiplied by the midpoint of the class and the results were summed and divided by the total number of debitage within the level. The results of these calculations as well as sample sizes and the percentages of flakes in the two smallest (110 and $11-20 \mathrm{~mm}$ ) size classes within the three excavation units are shown in Table 11.

For example, a total of 63 flakes were recovered from Level 2 of TU 1 and were distributed in five size classes from $1-10 \mathrm{~mm}$ to $41-50 \mathrm{~mm}$. The number of specimens in each size class is $2,44,11,5$, and 1 , respectively. To determine the mean flake size for Level 2 in TU 1, the size contribution of each of the five size classes was summed and divided by 63 (the total for the level). As $5 \mathrm{~mm}$ is the midpoint of the first size class $(1-10 \mathrm{~mm})$ and as 2 flakes were present, the $1-10 \mathrm{~mm}$ group contributed $10 \mathrm{~mm}$ (i.e., $2 \times 5$ $\mathrm{mm})$ to the overall level. The 11-20 mm class had 44 items, and contributed $660 \mathrm{~mm}(44 \times 15 \mathrm{~mm})$, the 21$30 \mathrm{~mm}$ class contributed $275 \mathrm{~mm}(11 \times 25 \mathrm{~mm})$, the $31-$ 40 size class was $175 \mathrm{~mm}(5 \times 35 \mathrm{~mm})$, and the 41-50 size class contributed $45 \mathrm{~mm}(1 \times 45 \mathrm{~mm})$. These size class contributions were summed for a total of 1165 $\mathrm{mm}$. This total length was divided by 63 to produce a mean length for the level of $18.5 \mathrm{~mm}$ (see Table 11).
A number of interesting patterns are notable:

1) Large and small mean flake sizes alternate by level, particularly within the upper levels of TUs 1 (Levels 1-6) and 3 (Levels 2-5);

2) The expected pattern of decreasing mean debitage sizes with increasing depth only occurs below Level 7 in TU 1, and below Level 5 in TU 2 and below Level 6 in TU 3;

3) Large mean flake sizes tend to correlate with smaller samples while smaller mean flake sizes tend to be observed in levels with larger sample sizes;

4) The larger sample sizes tend to have a greater proportion of debitage in the two smallest size categories; and

5) The debitage size distributions derived from TU 2 do not conform to the patterns noted in TUs 1 and 3 .

Although the distribution of the mean debitage size classes suggests some interesting differences with increasing depth, the potential depositional surfaces do not correspond with any of the geomorphologic zones identified in these units. Furthermore, the small size of the samples of platform-bearing flakes (complete specimens and proximal fragments) within each potential depositional group precludes in-depth comparative analyses to identify technological similarities and/ or differences. Nonetheless, the intriguing patterns noted in these data suggest that this line of inquiry should be pursued in future analyses of larger lithic debitage samples obtained from the area. 


\section{Summary and Recommendations}

Between April 30 and June 3, 1998, personnel from CAR-UTSA conducted archaeological investigations associated with the installation of a water pipeline for SWTSU. The installation was performed by DuMore Construction. The area to be impacted by the proposed water line included tracts on the banks of the headwater of the San Marcos River (known to be located within the boundaries of site 41HY161). The archaeological investigation included twenty-six shovel tests, two backhoe trenches, the excavation of three $1 \times 1-\mathrm{m}$ test units, and the monitoring of the pipeline installation.

The shovel tests were excavated in the proposed water pipeline route running from Joe's Crab Shack to the artesian well west of the Aquatic Biology Building. For management purposes, the route was divided into four sections: Section 1 -located immediately behind Joe's Crab Shack, Section 2 -between Sessom Drive and the Aquatic Biology Building, Section 3 behind the east end of the same building, and Section 4 -west of the Aquatic Biology Building.

Twelve shovel tests (STs 1-12) were excavated in Section 1 , half of these were dug in the original pipeline route while the other six were dug in the alternate route chosen by DuMore engineers. All but one of the units (ST 4) revealed extensive anthropogenic disturbances extending to a depth of $60 \mathrm{~cm}$ bs in this section. ST 4 contained undisturbed deposits beginning at $20 \mathrm{~cm}$ bs. Three (STs 15-17) of the five shovel tests (STs 13-17) excavated in Section 2 revealed primarily intact deposits. Artifact recovery was low in this area. One of the two shovel tests (ST 18) dug in Section 3 revealed highly disturbed deposits in the vicinity of the southeast corner of the Aquatic Biology Building. The seven shovel tests (STs 20-26) excavated in Section 4 provided the highest artifact recovery and exhibited the least disturbance. In general, they revealed disturbed soils in the upper two-three levels, and decreased anthropogenic disturbances below.

Based on shovel test data, it was determined that Section 4 had the potential for containing undisturbed archeological deposits. Therefore, three $1 \times 1$ meter units were excavated centered on STs 23, 24, and 25, respectively. All three units were placed in the immedi- ate area to be impacted by the planned water pipeline, in accordance with recommendations by THC.

TU 1 proved to be the least disturbed and contained valuable archaeological data. A total of nine arbitrary levels were excavated, and a total of eight geomorphologic zones were identified and described. The top three excavation levels (Levels $1-3,16-50 \mathrm{~cm}$ bd) had been disturbed by previous parking lot construction, sprinkler system installation, and landscaping activities (i.e., sod placement).

Two fragments of human cranial bone, which refit along an old break, were recovered from Level 1. No other evidence of human skeletal remains were found during this testing, although the area is in close proximity to two known Prehistoric burials (Garber and Glassman 1992).

Buried A horizons were identified within Zone 4 (29$49 \mathrm{~cm} \mathrm{bd}$ ), Zone 6 (52-68 cm bd), and Zone 8 (99$110+\mathrm{cm} \mathrm{bd})$. A large number of artifacts were recovered from the unit. They include a Late Archaic Williams stem fragment (Level 7, 80-90 cm bd; Figure $2 b$ ), a proximal Early Archaic Martindale fragment (Level 8, 90-100 cm bd; Figure 2c), and the mid-section of an untypeable late Paleoindian point from the same level (Figure 2d). The recovery of a Late Archaic point fragment in the bottom of geomorphologic Zone 7 (68-99 cm bd) suggests some degree of disturbance given that it is only $10 \mathrm{~cm}$ above an Early Archaic and a late Paleoindian point.

TU 2 was excavated to a depth of $70 \mathrm{~cm} \mathrm{bs}(87 \mathrm{~cm}$ bd). Although no obvious signs of anthropogenic disturbances were noted below Level $2(10-20 \mathrm{~cm}$ bd), the large number of roots found in all but the deepest level may have significantly bioturbated the deposits. Levels 2-7 contained moderate numbers of unmodified debitage but no temporal diagnostic artifacts. Debitage counts appeared to peak between $50-70 \mathrm{~cm}$ bd, decreasing with depth thereafter (Appendix 2). Five geomorphologic zones were identified in the south wall profile. None of them appear to represent buried paleosols.

TU 3 was excavated to a depth of $100 \mathrm{~cm}$ bd. Lithic debitage was present in all levels although two peaks can be clearly noted at $40-50 \mathrm{~cm}$ bd and $80-90 \mathrm{~cm}$ bd 
(Tables 9 and 10; Appendix 2). Two "Early CornerNotched" or "Split Stem" points were recovered in Levels $3(40-50 \mathrm{~cm} \mathrm{bd})$ and $4(50-60 \mathrm{~cm} \mathrm{bd}$; Figure $2 \mathrm{e}-\mathrm{f})$, respectively. It is possible that these points are associated with the first peak in debitage, which suggests that the second deeper peak may represent an even older occupation zone. Unfortunately, the recovery of fragments of clear and brown glass at 60-70 $\mathrm{cm}$ bd (Appendix 2) suggests some degree of disturbance. The presence of roots throughout the unit raises the possibility that the disturbance may be due to bioturbation alone. Four geomorphologic zones were identified within the unit. Zone $4(84-98 \mathrm{~cm} \mathrm{bd})$ was a very dark grayish brown (10YR3/2) clay loam with very common snail shells, few limestone gravels. This zone is equivalent to the deepest of the buried paleosols (Zone 8 [99-110+ cm bd]) observed in Test Unit 1. The lower boundary of the zone was not defined because the unit was terminated at a depth of $100 \mathrm{~cm}$ bd.

Two backhoe trenches (BHTs) were excavated to examine the geological and cultural stratigraphy in the project area (Figure 1). BHT 1 was placed in Section 1 in order to investigate the extent of cultural materials documented in STs 9-10, and to explore the potential for deeper deposits that might be impacted during the excavation of Bore Pit 1. BHT 2 was located perpendicular to the bank of a small spring-fed tributary known as Sessom Creek. It was oriented north-south so that it cross-cut the proposed pipeline route.

Eight extensively disturbed stratigraphic soil zones were identified in the north wall profile of BHT 1 (Figure 3). The area appeared to be highly disturbed by the construction and demolition of historic and modern buildings. Three stratigraphic soil zones were identified in the west wall of BHT 2 (Figure 4). The eroding, graded bank of the drainage was visible in all three zones. Intact, Prehistoric material-bearing deposits do not appear to exist in this section of the project area.

Two bore pits (BPs) were excavated by DuMore Construction in the location of the two backhoe trenches. Both bore pits were dug without prior notification of the project archaeologists. The largest of the pits (BP 1) was dug on top of BHT 1. A visual inspection of exposed portions of this bore pit was made approximately one week after its excavation. The second bore pit (BP 2), placed on BHT 2, was not investigated due to the presence of contaminated soils within the pit.

The profile of the west wall of the bore pit contained 6 geomorphologic zones. Most notable of these is Zone $6(110-300 \mathrm{~cm} \mathrm{bs})$. This yellowish-red clay loam zone is probably the same soil zone described by Shiner (1983) as the main cultural material-bearing deposits on the banks of the San Marcos River.

A small number of artifacts were collected from in situ within the profile of the west wall of BP 1 . The most notable of these finds is a Victoria point (Kelly (1983:20; see Figure 2b) recovered from a depth of $170 \mathrm{~cm}$ bs in the undisturbed section of the west wall. A number of Victoria (Thrall at Wilson-Leonard as per M. B. Collins) points recovered from the WilsonLeonard site date between 8,400-7,900 BP (Bousman 1999, personal communication).

An exposed utility trench (approx. $2.5 \mathrm{~m} \mathrm{x} 1 \mathrm{~m} \mathrm{x} .7$ $\mathrm{m}$ ), was dug by San Marcos City Utilities crews prior to the beginning of the project at the west end of the project area adjacent the parking lot (Figure 1). The backfill, walls, and floor of the trench were inspected for cultural resources. Three geomorphologic zones were noted in the trench. Zones 1 and 2 were extensively disturbed, while Zone 3 appeared to be less disturbed and contained only Prehistoric artifacts (e.g., unmodified debitage and burned limestone). Several artifacts were collected from the backdirt including a Bulverde stem.

In summary, test excavations conducted in the proposed raw water pipeline route revealed that throughout the project area the upper $30 \mathrm{~cm}$ of deposits were highly disturbed and contained a mix of Modern, Historic, and Prehistoric cultural materials. Below $30 \mathrm{~cm}$ and extending to a depth of $80 \mathrm{~cm}$ deposits are undisturbed and contain a moderate density of Early Archaic cultural materials. Two truncated A horizons were identified in TU 1 between $29-68 \mathrm{~cm}$ bd. A third buried A horizon is present at a depth of approximately $90 \mathrm{~cm}$ below surface. The mid-section of a Late Paleoindian, possibly Angostura, projectile point was recovered at a depth of $90 \mathrm{~cm}$ bs from the top of this 
paleosol. Organic matter from this soil (Test Unit 1, Zone 8) was submitted for radiocarbon dating to Beta Analytic Incorporated. The resulting estimate of $1060 \pm 70$ BP (Beta-132889, ${ }^{13} \mathrm{C}=-20.1 \%$ ) reflects a serious contamination problem with modern organic matter. Based on calcium carbonate content and the age of the projectile point, it is our contention that this paleosol appears to be of late Pleistocene age. Excavation units that proceeded through this paleosol continued to recover moderate densities of archaeological materials to a depth of $100 \mathrm{~cm}$ bs. No excavation units were dug below $100 \mathrm{~cm}$ bs as per THC recommendations.

Upon completion of the original testing efforts, CAR determined that no intact cultural resources would be impacted by the planned trench construction between the west bank of the San Marcos River and the southeast end of the Aquatic Biology Building. Therefore, clearance for the pipeline route was recommended in areas that did not contain cultural resources and in areas that had been disturbed by recent or historic construction. In these areas the pipeline trench excavation was permitted to proceed to a depth of 25 inches below the surface.

During testing intact cultural materials were identified within the pipeline route west of the Aquatic Biology Building. CAR staff archaeologists advised the client that data recovery would be necessary in this portion of the route if construction was to continue as designed in the original scope of work. To contain costs, SWTSU was opposed to any further data recovery. In a compromise worked out between THC and SWTSU personnel (letter: July 9, 1998; to: Allen Henderson, SWTSU Physical Plant, from: James Bruseth, THC Deputy State Historic Preservation Officer) it was decided to limit the depth of the pipeline trench to 12 inches $(30 \mathrm{~cm})$ below surface in the portion of the pipeline route containing buried intact deposits. This strategy impacted only the uppermost portion of the intact soils and prevented disturbing the more significant deeper cultural deposits. CAR personnel were present as the pipeline was laid in the trench during monitoring.

If at all possible, future construction-related disturbances should be limited to the uppermost $30 \mathrm{~cm}$ of deposits. If deeper disturbances cannot be avoided it is recommended that mitigation of these disturbances be carried out through the careful recovery of representative samples of the Early Archaic and Paleoindian components found west of the Aquatic Biology Building. In particular, attention should be focused on determining the ages of the three buried paleosols and identifying and/or clarifying the nature of the depositional surfaces suggested by the analysis of the unmodified debitage. 


\section{References Cited}

Arnn, J. W. III

1997 Archaeological Monitoring of a Sidewalk Construction Project in Landa Park, New Braunfels, Comal County, Texas. Archaeological Survey Report, No. 254. Center for Archaeological Research, The University of Texas at San Antonio.

Batte, C. D.

1984 Soil Surveys of Comal and Hays Counties, Texas. Soil Conservation Service, Temple.

Birmingham, W. W., and T. R. Hester

1976 Late Pleistocene Archaeological Remains from the Johnston-Heller Site, Texas Coastal Plains. Special Report No. 3. Center for Archaeological Report, The University of Texas at San Antonio.

Black, S. L.

1989a Environmental Setting. In From the Gulf Coast to the Rio Grande: Human Adaptation in Central, South, and Lower Pecos Texas, edited by T. R. Hester, S. L. Black, D. G. Steele, B. W. Olive, A. A. Fox, K. J. Reinhard, and L. C. Bement, pp. 5-16. Research Series No. 33 Arkansas Archaeological Survey, Fayetteville.

1989b Central Texas Plateau Prairie. In From the GulfCoast to the Rio Grande: Human Adaptation in Central, South, and Lower Pecos Texas, edited by T. R. Hester, S. L. Black, D. G. Steele, B. W. Olive, A. A. Fox, K. J. Reinhard, and L. C. Bement, pp. 17-38. Research Series No. 33 Arkansas Archaeological Survey, Fayetteville.

Blair, W. F.

1950 The Biotic Provinces of Texas. Texas Journal of Science 2(1):93-117

Bolton, H. E.

1908 The Native Tribes about the East Texas Missions. Texas State Historical Association Quarterly 11:249276.

1915 Texas in the Middle Eighteenth Century: Studies in Spanish Colonial History and Administration. Reprint, 1970. University of Texas Press, Austin.

Bousman, C. B.

1998 Paleoenvironmental Change in Central Texas: The Palynological Evidence. Plains Anthropologist 43(164):201-219.

Boxall, B.

1976 Technology Closed SM Ice House. In The San Marcos Daily Record. July 1, 1976.

Brune, G.

1975 Major and Historical Springs of Texas. Report No. 189. Texas Water Development Board.

1981 Springs of Texas, Vol. 1. Branch-Smith, Inc. Fort Worth, Texas. 
Campbell, T. N., and T. J. Campbell

1985 Indian Groups Associated with Spanish Missions of the San Antonio Missions National Historical Park. Special Report, No. 16. Center for Archaeological Research, The University of Texas at San Antonio.

Cargill, D., and M. Brown

1997 Archaeological Testing at Crook's Park in San Marcos, Hays County, Texas. Archaeological Survey Report No. 263. Center for Archaeological Research, The University of Texas at San Antonio.

Collins, M. B.

1995 Forty years of Archaeology in Central Texas. Bulletin of Texas Archaeological Society 66:361-400.

Ford, O. A., and A. S. Lyle

1998 Archaeological Investigation of a Spring Lake Lot for Joe's Crab Shack Parking. Archaeological Survey Report No. 277. Center for Archaeological Research, The University of Texas at San Antonio.

Foster, W. C.

1995 Spanish Expeditions into Texas 1689-1768. University of Texas Press, Austin.

Garber, J. F., S. Bergman, B. Dickinson, R. Hays III, J. Simpson, and J. Stefanoff

1983 Excavations at Aquarena Springs, 41HY160, San Marcos, Texas. La Tierra:10(2):38-38.

Garber, J., and M. D. Orloff

1984 Excavations at 41HY37: An Archaic Site on the Balcones Escarpment in San Marcos, Texas. La Tierra:11(3):31-37.

Garber, J., and D. Glassman

1992 Excavations of Human Remains from the Fish Pond Site, 41 HY161 in San Marcos, Hays County, Texas. TAC Permit \#338. Unpublished report on file at the Department of Sociology/Anthropology. Southwest Texas State University, San Marcos.

Gilmore, K. K.

1969 The San Xavier Missions: A Study in Historical Site Identification (1746-1755). Report No. 16. State Building Commission Archaeological Program, Austin.

Harris, E. S.

1985 The Timmeron Rockshelter (41HY95), Hays County, South Central Texas. Special Publication No. 4, South Texas Archaeological Association, San Antonio.

Hatcher, M. A. A.

1976[1927] The Opening of Texas to Foreign Settlement. Porcupine Press, Philadelphia.

Hester, T. R.

1971 Archeological Investigations at the La Jita Site, Uvalde County, Texas. Bulletin of the Texas Archeological Society 42:51-148.

1995 The Prehistory of South Texas. Bulletin of the Texas Archaeological Society 66:427-529. 
Johnson, L., and G. T. Goode

1995 Chapter 4: Holocene Climates and Archaeological Periods on the Eastern Edwards Plateau. In Past Cultures and Climates at Jonas Terrace, 41 ME29 Medina County, Texas, pp. 70-102. Report No. 40. Office of the State Archeologist, Austin.

Jones, J. T.

1997 Research Notes on Spanish Colonial Documents Regarding the Camino de Arriba, and San Marcos de Neve. Translated manuscript, on file at Paul Price Associates, Inc., Austin.

Kelly, T. C.

1983 The Brom Cooper Paleo-Indian Collection from McMullen County, Texas. La Tierra 10(3):17-40.

McCulloch, S., and M. Voellinger

1996 Cultural Resources Investigation of the Henry Tract, San Marcos, Hays County, Texas. Antiquities Permit No. 1420. SAGE Environmental Archaeology Series 10. S. A. Garza Engineers, Inc., Austin.

McGraw, A. J., J. W. Clark, Jr., and E. A. Robbins

1991 A Texas Legacy, The Old San Antonio Road and the Caminos Reales: A Tricentennial History 16911991. Texas State Department of Highways and Public Transportation, Austin.

McKinney, W. W.

1981 Early Holocene Adaptations in Central and Southwestern Texas: The Problem of the PaleoindianIndian-Archaic Transition. Bulletin of the Texas Archaeological Society 52:91-120.

Mitchell, J. L.

1976 A Tentative New Type of Late Paleo-Indian Point from South Texas. La Tierra 3(1):20-23.

Ogden, A. E., R. A., Quick, and S. R. Rothermel

1986 Hydrochemistry of the Comal, Hueco, and San Marcos Springs, Edwards Aquifer, Texas. In The Balcones Escarpment: Geology, Hydrology, Ecology and Social Development in Central Texas. Geological Society of America Annual Meeting. San Antonio.

Ricklis, R. A., M. D. Blum, and M. B. Collins

1991 Archeological Testing at the Vera Daniel Site (41TV1364), Zilker Park, Austin, Texas. Studies in Archeology 12. Texas Archeological Research Laboratory, The University of Texas at Austin.

Ricklis, R. A., and M. B. Collins

1994 The Environmental Context. In Archaic and Late Prehistoric Human Ecology in the Middle Onion Creek Valley, Hays County, Texas, edited by M. B. Collins and R. A. Ricklis, 1:27-36. Studies in Archeology 19. Texas Archeological Research Laboratory, The University of Texas at Austin.

Salinas, M.

1990 Indians of the Rio Grande Delta Their Role in the History of Southern Texas and Northeastern Mexico. University of Texas Press, Austin. 
Shiner, J.

1979 Survey and Testing of the Ice House Site: San Marcos, Hays County, Texas. Unpublished Report for Texas Antiquities Permit 194. Southern Methodist University, Dallas.

1983 Large Springs and Early American Indians. In Plains Anthropologist 28(99):1-7.

Takac, P. R., Jr.,

1990 "Homebases" and the Paleoindian/Archaic Transition in central Texas. Paper presented at 55th Annual Meeting of the Society for American Archaeology. Las Vegas, Nevada.

Tijerina, A.

1994 Tejanos \& Texas under the Mexican Flag, 1821-1836. Texas A\&M University Press, College Station.

Turner, E. S., and T. R. Hester

1993 A Field Guide to Stone Artifacts of Texas Indians. Second Edition. Texas Monthly Field Guide Series, Gulf Publishing Co., Houston. 


\section{Appendix 1 \\ List of Artifacts from Shovel Tests by Level}


Appendix 1. List of artifacts recovered from all shovel tests by level.

\begin{tabular}{|c|c|c|c|c|c|c|c|c|}
\hline Shovel & & Chipped & Animal & Misc. & Misc. & European & & \\
\hline Test & Level & Lithics & Bone & Metal & Glass & Ceramic & Other & Total \\
\hline 1 & 1 & 1 & & & & & 1 penny, 5 plastic & 7 \\
\hline 1 & 2 & & & & 1 & & 5 slag, 1 plastic pc. & 7 \\
\hline 1 & 3 & 5 & 1 & & & & & 6 \\
\hline 1 & 4 & & & & & & 2 slag & 2 \\
\hline 1 & 5 & 1 & 4 & 2 (1 sq. nail) & 1 & & 1 fossil snail & 9 \\
\hline 1 & 6 & & & & 1 & & 2 plastic pc. & 3 \\
\hline Total & & 7 & 5 & 2 & 3 & 0 & 17 & 34 \\
\hline 2 & 1 & & & 1 wire nail & & & 2 pennies & 3 \\
\hline 2 & 2 & & & & 2 & 1 & 1 penny '1981' & 4 \\
\hline 2 & 3 & 4 & & 2 sq. nails & & & & 6 \\
\hline 2 & 4 & 2 & 1 & & & & 4 brick w/mortar & 7 \\
\hline 2 & 5 & & 1 & 3 & & & 1 slag & 5 \\
\hline 2 & 6 & 1 & 3 & 1 & & & & 5 \\
\hline Total & & 7 & 5 & 7 & 2 & 1 & 8 & 30 \\
\hline 3 & 2 & 1 & & & & & & 1 \\
\hline 3 & 3 & 1Pedernales Pnt. & & & & & & 1 \\
\hline 3 & 4 & 3 & & & & & & 3 \\
\hline 3 & 5 & 3 & 3 & & 1 & & & 7 \\
\hline Total & & 8 & 3 & 0 & 1 & 0 & 0 & 12 \\
\hline 4 & 2 & 6 & & & 1 & & & 7 \\
\hline 4 & 3 & 12 & 2 & & & & & 14 \\
\hline 4 & 4 & 4 & & & & & & 4 \\
\hline 4 & 5 & 4 & & & & & & 4 \\
\hline 4 & 6 & 4 & 2 & & & & & 6 \\
\hline Total & & 30 & 4 & 0 & 1 & 0 & 0 & 35 \\
\hline 5 & 1 & & & 1 sq. nail & & & 2 brick & 3 \\
\hline 5 & 2 & 1 & & & & & & 1 \\
\hline 5 & 3 & 2 & & 1 sq. nail & & & & 3 \\
\hline 5 & 4 & 4 & & 1 & & 1 & & 6 \\
\hline 5 & 5 & 2 & & & & & & 2 \\
\hline Total & & 9 & 0 & 3 & 0 & 1 & 2 & 15 \\
\hline 6 & 1 & 2 & & & & & & 2 \\
\hline 6 & 2 & & & 2 wire nails & & & & 2 \\
\hline 6 & 3 & 1 & & & & & & 1 \\
\hline Total & & 3 & 0 & 2 & 0 & 0 & 0 & 5 \\
\hline 7 & 1 & 2 & & 1 & & & 1 coal pc. & 4 \\
\hline 7 & 2 & & & 2 wire nails & 1 & & & 3 \\
\hline 7 & 3 & & & & & & & 0 \\
\hline Total & & 2 & 0 & 3 & 1 & 0 & 1 & 7 \\
\hline 8 & 1 & 2 & & 2 wire nails & & & 1 coal pc. & 5 \\
\hline 8 & 2 & 1 & & & & & & 1 \\
\hline 8 & 3 & 7 & & & & & & 7 \\
\hline 8 & 5 & 4 & & & & & & 4 \\
\hline Total & & 14 & 0 & 2 & 0 & 0 & 1 & 17 \\
\hline 9 & 1 & 6 & 6 & 2 & 1 & 1 & & 16 \\
\hline 9 & 2 & 5 & & 3 & 1 & & & 9 \\
\hline 9 & 3 & 2 & 1 & & & 1 & 3 slag & 7 \\
\hline 9 & 4 & & & & & & 10 slag & 10 \\
\hline 9 & 5 & & & & & & 7 coal and slag & 7 \\
\hline 9 & 6 & & & & & & & 0 \\
\hline Total & & 13 & 7 & 5 & 2 & 2 & $\begin{array}{r}20 \\
\end{array}$ & 49 \\
\hline 10 & 2 & 1 & & & 2 & & 1 penny & 4 \\
\hline 10 & 3 & & & & & & 1 plastic button & 1 \\
\hline 10 & 4 & & & & & & 7 slag & 7 \\
\hline 10 & 5 & & & & & & 10 slag & 10 \\
\hline Total & & 1 & 0 & 0 & 2 & 0 & 19 & 22 \\
\hline
\end{tabular}


Appendix 1, continued...

\begin{tabular}{|c|c|c|c|c|c|c|c|c|}
\hline Shovel & & Chipped & Animal & Misc. & Misc. & European & & \\
\hline Test & Level & Lithics & Bone & Metal & Glass & Ceramic & Other & Total \\
\hline 11 & 3 & 1 & 0 & 0 & 0 & 0 & 0 & 1 \\
\hline Total & & 1 & & & & & & 1 \\
\hline 12 & 1 & 1 & & 1 & & & & 2 \\
\hline 12 & 2 & 3 & & 1 & & & 2 pennies & 6 \\
\hline 12 & 3 & & & & & & 1 slag & 1 \\
\hline 12 & 4 & & & & & & 6 slag & 6 \\
\hline Total & & 4 & 0 & 2 & 0 & 0 & 9 & 15 \\
\hline 13 & 2 & 1 & & & 1 & & & 2 \\
\hline 13 & 5 & & & 1 spike & & & 1 yellow brick & 2 \\
\hline 13 & 6 & & & & & & 1 indet. & 1 \\
\hline Total & & 1 & 0 & 1 & 1 & 0 & 2 & 5 \\
\hline 14 & 3 & & & 1 & & & & 1 \\
\hline Total & & 0 & 0 & 1 & 0 & 0 & 0 & 1 \\
\hline 17 & & & & & & & & 0 \\
\hline Total & & 0 & 0 & 0 & 0 & 0 & 0 & 0 \\
\hline 18 & 1 & & & & & & 1 red brick & 1 \\
\hline 18 & 2 & & & & & & 12 red brick & 12 \\
\hline 18 & 3 & 1 & & 1 & & & 8 red brick & 10 \\
\hline 18 & 4 & & & & 1 & & & 1 \\
\hline Total & & 1 & 0 & 1 & 1 & 0 & 21 & 24 \\
\hline 20 & 2 & 1 & & & & & & 1 \\
\hline 20 & 3 & 3 & & & & & & 3 \\
\hline Total & & 4 & 0 & 0 & 0 & 0 & 0 & 4 \\
\hline 21 & 4 & 1 & & & & & & 1 \\
\hline Total & & 1 & 0 & 0 & 0 & 0 & $\begin{array}{l}0 \\
\end{array}$ & 1 \\
\hline 22 & 1 & 2 & & & & & 19 red brick & 21 \\
\hline 22 & 2 & & & 1 & & & 52 red brick & 53 \\
\hline 22 & 3 & 2 & 2 & 3 & & & 75 red brick & 82 \\
\hline 22 & 5 & 2 & & & & & & 2 \\
\hline Total & & 6 & 2 & 4 & 0 & 0 & \begin{tabular}{|l|}
146 \\
\end{tabular} & 158 \\
\hline 23 & 1 & 1 & & & & & 3 red brick & 4 \\
\hline 23 & 2 & 1 & & 1 & & & & 2 \\
\hline 23 & 3 & & 3 & & & & & 3 \\
\hline 23 & 4 & 1 & 10 & & & & & 11 \\
\hline 23 & 5 & 2 & 4 & & & & & 6 \\
\hline 23 & 6 & 8 & 7 & & & & 3 burned rock & 18 \\
\hline Total & & 13 & 24 & 1 & 0 & 0 & \begin{tabular}{|l}
6 \\
\end{tabular} & 44 \\
\hline 24 & 1 & 4 & 1 & 1 & & & 1 brick & 7 \\
\hline 24 & 2 & 1 & & & & & & 1 \\
\hline 24 & 3 & 1 & & & & & & 1 \\
\hline Total & & 6 & 1 & 1 & 0 & 0 & 1 & 9 \\
\hline 25 & 1 & 2 & & 8 & & & 1 wire & 11 \\
\hline 25 & 3 & 2 & 1 & & & & & 3 \\
\hline 25 & 5 & 3 & & & & & & 3 \\
\hline Total & & 7 & 1 & 8 & 0 & 0 & 1 & 17 \\
\hline 26 & 1 & 1 & & & & & & 1 \\
\hline 26 & 3 & 1 & & & & & & 1 \\
\hline 26 & 4 & 1 & & & & & & 1 \\
\hline Total & & 3 & 0 & 0 & 0 & 0 & 0 & 3 \\
\hline \multicolumn{9}{|l|}{ Grand } \\
\hline Total & & 141 & 52 & 43 & 14 & 4 & 254 & 508 \\
\hline
\end{tabular}


Appendix 2

List of Artifacts from Units by Level 
Appendix 2. List of artifacts recovered from all test units by level..

\begin{tabular}{|c|c|c|c|c|c|c|c|c|c|c|c|c|}
\hline & & Depth & & Lithic & Animal/Human & Misc. & Misc. & European & & Constr. & Snails/Mussel & \\
\hline Unit & Level & bd & Flakes & Tools & Bone & Metal & Glass & Ceramics & FCR & Debris & Shell & Other \\
\hline 1 & 1 & $13-30$ & 15 & 1 unt. Medial D.P. frag;, 1 graver & 4 & 10 & & & & 362 & & \\
\hline 1 & 2 & $30-40$ & 63 & 1 scraper; 1 misc. biface & & 4 & & & & 6 & & \\
\hline 1 & 3 & $40-50$ & 42 & & 1 & & & & & & & \\
\hline 1 & 4 & $50-60$ & 131 & 1 misc. biface; 1 scraper; 2 knives & & & & & & & & \\
\hline 1 & 5 & $60-70$ & 87 & 2 misc. bifaces; 3 scrapers & & & & 1 & & & & \\
\hline 1 & 6 & $70-80$ & 100 & & & & & & & & 47 & \\
\hline 1 & 7 & $80-90$ & 55 & 1 DP stem frag., Williams & & & & & & & 35 & \\
\hline 1 & 8 & $90-100$ & 90 & 2 misc. bif.; 1 Paleo., point frag.; 1 Martindale & & & & & & & 13 & \\
\hline \multirow[t]{2}{*}{1} & & 100-110 & 75 & 3 scrapers; 1 misc. uniface & 11 & & & & 9 & & 6 & 1 seed \\
\hline & \multicolumn{2}{|c|}{ Unit Totals } & 658 & 22 & 16 & 14 & 0 & 1 & 9 & 368 & 101 & 1 \\
\hline & & & & & & & & & & & & \\
\hline 2 & 1 & $13-30$ & 10 & & 1 & 16 & & & & 2 & & \\
\hline 2 & 2 & $30-40$ & 13 & 1 scraper; 1 core & & 3 & & & 5 & & & \\
\hline 2 & 3 & $40-50$ & 25 & 1 misc., biface & & & & & 7 & & & \\
\hline 2 & & $50-60$ & 56 & 1 scraper; 1 knife & 5 & & & & 4 & & 3 & \\
\hline 2 & & $60-70$ & 49 & 3 scrapers; 1 knife; 2 misc. bifaces & & & & & 19 & & & \\
\hline 2 & & $70-80$ & 37 & 1 misc., biface & & & & & 7 & & & \\
\hline \multirow[t]{2}{*}{2} & & $80-90$ & 27 & 2 misc. bifaces & & & & & 1 & & & \\
\hline & \multicolumn{2}{|c|}{ Unit Totals } & 217 & 14 & 6 & 19 & 0 & 0 & 43 & 2 & 3 & 0 \\
\hline & & & & & & & & & & & & \\
\hline 3 & 1 & $10-30$ & 9 & 1 misc. biface; 1 scraper & 1 & & & & 3 & & & 2 latex pc. \\
\hline 3 & 2 & $30-40$ & 12 & & & & 2 & & 3 & & & \\
\hline 3 & 3 & $40-50$ & 99 & 1 early corner-notched point; 1 misc. uniface & 10 & & & & 18 & & & 2 burned mat. \\
\hline 3 & 4 & $50-60$ & 48 & 1 early corner-notched point; 1 scraper & 2 & & & & 6 & & 8 & \\
\hline 3 & 5 & $60-70$ & 60 & & 4 & & 2 & & 17 & & 2 & \\
\hline 3 & 6 & $70-80$ & 42 & 1 misc. biface & & & & & 6 & & & \\
\hline 3 & 7 & $80-90$ & 106 & 2 misc. bifaces; 2 scrapers & 1 & & & & 11 & & 47 & \\
\hline \multirow[t]{4}{*}{3} & & $90-100$ & 59 & 2 misc. bifaces & & & & & 1 & & & \\
\hline & \multicolumn{2}{|c|}{ Unit Totals } & 435 & 13 & 18 & 0 & 4 & $\mathbf{0}$ & 65 & 0 & 57 & 4 \\
\hline & & & & & & & & & & & & \\
\hline & \multicolumn{2}{|c|}{ Grand Totals } & 1310 & 49 & 40 & 33 & 4 & 1 & 117 & 370 & 161 & 5 \\
\hline
\end{tabular}

